Canadian Science Publishing

Canadian Journal of Earth Sciences Revue canadienne des sciences de la Terre

The Pele Offset Dykes, Sudbury impact structure, Canada

\begin{tabular}{|r|l|}
\hline Journal: & Canadian Journal of Earth Sciences \\
\hline Manuscript ID & cjes-2017-0146.R1 \\
\hline Danuscript Type: & Article \\
\hline Complete List of Authors: & $\begin{array}{l}\text { Pilles, Eric; University of Western Ontario, Earth Sciences } \\
\text { Osinski, Gordon; University of Western Ontario, Depts. of Earth Sciences, } \\
\text { Physics \& Astronomy } \\
\text { Grieve, Richard; University of Western Ontario, Earth Sciences } \\
\text { Coulter, Adam; Centre for Planetary Science and Exploration } \\
\text { Smith, David; Wallbridge Mining Company Limited } \\
\text { Bailey, Joshua; Wallbridge Mining Company Limited }\end{array}$ \\
\hline $\begin{array}{r}\text { Is the invited manuscript for } \\
\text { consideration in a Special }\end{array}$ & N/A \\
\hline Keywe? : & \\
\hline Keyword: & Sudbury, Offset Dyke, Impact Crater, Geochemistry, Petrography \\
\hline
\end{tabular}

SCHOLARONE $^{\text {Ix }}$

Manuscripts 


\section{The Pele Offset Dykes, Sudbury impact structure, Canada}

E. A. PILLES ${ }^{1 *}$, G. R. OSINSKI ${ }^{1,2}$, R. A. F. GRIEVE ${ }^{1}$, A. B. COULTER ${ }^{1}$, D. $\mathrm{SMITH}^{3}$, and J. BAILEY ${ }^{3}$

${ }^{1}$ Dept. Earth Sciences / Centre for Planetary Science and Exploration, University of Western Ontario, London, Ontario, N6A 5B7, Canada

${ }^{2}$ Dept. Physics and Astronomy, University of Western Ontario, London, Ontario, N6A 5B7, Canada

${ }^{3}$ Wallbridge Mining Company Limited, 129 Fielding Road, Sudbury, ON P3Y 1L7

*Corresponding author. E-mail: epilles@uwo.ca 
16 Abstract

17 The Offset Dykes are impact-melt bearing dykes related to the 1.85 Ga Sudbury impact structure.

18 Currently, the dykes extend radially outward from - or occur concentrically around - the

19 Sudbury Igneous Complex, which is the remnant of a differentiated impact melt sheet and the

20 source of the dykes. The recently identified three Pele Offset Dykes intrude into the Archean

21 rocks north of the Sudbury Igneous Complex. In this study, the Pele dykes are characterized for

22 the first time by a combination of fieldwork, optical microscopy, electron microprobe analyses,

23 and bulk geochemical analyses. The Pele Offset Dykes stand out from the other Offset Dykes at

24 Sudbury in two significant ways: (1) All other known Offset Dykes consist of an inclusion-rich

25 lithology in the centre of the dyke and an inclusion-poor lithology along the margins. The Pele

26 dykes, however, are only composed of the inclusion-poor phase. (2) The Pele dykes -

27 particularly the Central and Eastern dykes - have a more evolved chemical composition relative

28 to the other Offset Dykes. These observations suggest that the Pele dykes were emplaced after

29 the other known Offset Dykes during two injection events: the Western followed by the Central 30 and Eastern Pele dykes.

32 Keywords: Sudbury, Offset Dyke, impact crater, geochemistry, petrography 
33 52 geochemical analyses.

\section{Introduction}

The so-called Offset Dykes formed at $\sim 1.85 \mathrm{Ga}$, when impact melt material from the Sudbury impact event was injected into the fractured footwall rocks of the crater floor. The Offset Dykes have an average chemical composition of granodiorite, but their lithology is traditionally referred to as inclusion-poor quartz diorite (QD) and inclusion-rich quartz diorite (IQD). These traditional terms, although geochemical misnomers, are unfortunately entrenched in the literature and are, therefore, used herein. The Offset Dykes are an important host of Ni-Cu sulfide and PGE metal ores at Sudbury (e.g., Ames et al. 2008), but despite a long history of exploration there is still considerable controversy regarding their formation, particularly regarding the timing of their emplacement relative to the impact cratering process. For example, Murphy and Spray (2002) suggested that the Whistle and Parkin Offset Dykes were emplaced during two stages, one forceful outward injection of inclusion-rich quartz diorite (IQD), during the early excavation stage, and a second, inclusion-poor quartz diorite (QD), during the modification stage, of crater formation. By comparison, Lightfoot and Farrow (2002) proposed that the Worthington Offset Dyke formed from an early QD injection followed by a later injection of IQD. The recently discovered Pele Offset Dykes (Smith et al. 2013) are a small cluster of dykes located in the footwall rocks of the North Range of the Sudbury impact structure. In this study, the Pele Offset Dykes are characterized, for the first time, using a combination of field observations, optical microscopy, electron microprobe and whole rock 
The Sudbury impact structure is the remnant of a 1.85 Ga old, $\sim 150-200 \mathrm{~km}$ diameter

55 impact crater in central Ontario, Canada (Grieve et al. 2008). It is located at the present-day

56 contact between the Archean granite, greenstone, and gneiss terrain of the Superior Province to

57 the northwest, and the Paleoproterozoic metavolcanics and metasediments of the Southern

58 Province to the southeast (Fig. 1). The Sudbury impact structure consists of three major

59 components: 1) the Whitewater Group, post-impact sediments that now fill the Sudbury Basin; 2)

60 the Sudbury Igneous Complex (SIC), a 2.5-3 km thick differentiated impact melt sheet; and 3)

61 the fractured and brecciated footwall rocks surrounding the SIC (Dressler 1982; Grieve et al.

62 1991; Therriault et al. 2002; Rousell et al. 2003; Ames et al. 2008). The so-called Sublayer lies

63 below the Main Mass of the SIC, which is subdivided into five units. From the bottom of the

64 melt sheet to the top, the Main Mass of the SIC consists of: so-called Norite, Quartz Gabbro,

65 Transition Zone, Granophyre (Naldrett et al. 1970; Therriault et al. 2002), and Upper Contact

66 Unit (Anders et al. 2015).

67

68

69

70

71

72

73

74

75

76
The Offset Dykes are derived from the SIC and are composed generally of IQD in the centre of the dyke and QD along the margins of the dyke (Lightfoot et al., 1997). The dykes are subdivided into three groups based on their current orientation relative to the SIC (Grant and Bite 1984): (1) Concentric Offset Dykes oriented sub-parallel to the base of the current outcrop of the SIC (Fig. 1; e.g., Hess and Manchester), (2) Discontinuous or breccia-hosted Offset Dykes characterized by isolated pods of quartz diorite within Sudbury Breccia (e.g., Frood Stobie and MacLennan), and (3) Radial Offset Dykes radial to the current outcrop of the SIC (e.g., Pele, Copper Cliff, Worthington, Ministic, Foy, Whistle-Parkin, and Trill Offset Dykes).

The Pele Offset Dykes are located 500 m west of the well-known Foy Offset Dyke and consist of three separate radial dykes, which are referred to, herein, as the Western, Central, and 
77 Eastern Pele dykes (Fig. 2). They are primarily hosted in the Archean-aged Cartier Batholith of

78 the Superior Province. The Pele dykes also cut across several Nipissing diabase bodies, which

79 are found throughout the Sudbury region and are dated at 2219.4+3.6/-3.5 -3.5/+3.6 Ma (Corfu

80 and Andrews 1986). The Eastern Pele dyke was first studied by Tuchscherer (1998), who

81 referred to it as the "Parallel Foy". The Central and Western Pele dykes were recently discovered

82 by Wallbridge Mining Company Limited (Smith et al. 2013), who have trenched several new

83 outcrops at all three Pele dykes.

Previous research on the Pele Offset Dykes has been limited. Tuchscherer (1998)

observed an outcrop of the Eastern Pele dyke located north of the Hess (Fig. 1) and described the lithology of the dyke as a dark grey rock "devoid of inclusions" and composed of biotite and amphibole set in a groundmass of granophyric intergrowths of quartz and orthoclase. One sample from this region was analysed by Tuchscherer (1998), using X-Ray Fluorescence. Relative to the rest of the Foy dyke, Tuchscherer (1998) observed that the sample had elevated $\mathrm{SiO}_{2}$ content (60.7 wt. \%), a low Mg\# (0.16), and an enrichment in REE, and concluded that the Eastern Pele dyke likely originated from a more evolved source than the Foy dyke. A sample of the southern portion of the Eastern Pele dyke (Fig. 2) has been dated at 1848.5 $\pm 0.8 \mathrm{Ma}$, using U-Pb isotopic dating of baddeleyite (Bleeker et al. 2015) and is similar to the age of the SIC determined by Davis (2008), using ${ }^{207} \mathrm{~Pb} /{ }^{206} \mathrm{~Pb}$ isotopic dating of zircons $(1849.53 \pm 0.21 \mathrm{Ma}$ for the North Range Felsic Norite, and 1849.11 \pm 0.19 Ma for the South Range Norite). This study examines data from new trenches of the Pele dykes and uses petrographic and geochemical analysis to demonstrate that the dykes have some variation in terms of composition and differ from the nearby Foy Offset Dyke (Fig. 2).

\section{Methods}


Fieldwork was completed in the summers of 2013 and 2015 (Fig. 2). Thirty-two samples

101

102

103

104

105

106

107

108

109

110

111

112

113

114

115

116

117

118

119

120

121

122

were collected: nineteen from the Central Pele dyke, and twelve samples from the Western Pele

dyke. Due to lack of exposure, only one outcrop is known and, thus, one sample was collected from the Eastern Pele dyke. Eight samples of Nipissing Diabase in the proximity of Pele dykes were also collected. Thin sections were examined using optical microscopy. A JEOL JXA-8530F field-emission electron microprobe at Western University was used to analyse plagioclase from six samples (averages reported in Table 1). A counting time of 10 seconds was used, with an accelerating voltage of $20 \mathrm{kV}$, a beam current of $20 \mathrm{nA}$, and a beam size of $5 \mu \mathrm{m}$. Three types of corrections were applied to the data: atomic number correction, absorption correction, and fluorescence correction.

Samples were prepared for whole rock geochemical analysis at Western University. Samples were first crushed in a Chipmunk Jaw Crusher and clasts $>1 \mathrm{~mm}$ in size of local host rocks were removed manually using visual inspection. The remaining rock was powdered using a Micro Powder Grinding Mill for 60 seconds. Care was taken during this procedure to avoid cross-contamination of samples. The crusher was cleaned between each sample. After a sample was powdered, quartz sand was run through the mill before cleaning the mill.

The powder was sent to ALS Minerals in Vancouver, BC, for acid digestion and chemical analyses (Table 2). Two hundred milligrams of the sample were then mixed with $0.90 \mathrm{~g}$ of lithium metaborate and fused at $1000^{\circ} \mathrm{C}$. This mixture was dissolved in a $100-\mathrm{mL}$ solution of 4 $\% \mathrm{HNO}_{3}$ and $2 \% \mathrm{HCl}$. Major element oxides were analysed using inductively coupled plasmaatomic emission spectroscopy (ICP-AES) and the results were corrected for spectral interelement interferences. Oxide concentration is calculated from the determined elemental concentration and the result is reported in that format as weight percent oxide (wt. \%). Trace 
123 elements were analysed using inductively coupled plasma-mass spectrometry (ICP-MS) and the

124 results are reported as parts per million (ppm).

125 Geochemical data from Wallbridge Mining Company Limited was also included as a part

126 of this study (Table 2; Fig. 2). Clasts larger than $\sim 1 \mathrm{~cm}$ were removed from these samples, using

127 visual inspection. Samples were sent to ALS Minerals and were ground to a fine powder. Two

128 hundred fifty milligrams of the sample were then digested with four acid digestion (perchloric,

129 nitric, hydrofluoric and hydrochloric acids). The residue was topped up with dilute hydrochloric

130 acid and analysed by ICP-AES. Results are corrected for spectral inter-element interferences.

131 Representative analyses are available in Table 2, and the complete dataset is available as

132 supplementary information. The precision and accuracy of these measurements are $\pm 10 \%$ (of the

133 concentration \pm 1 limit of detection for duplicate analyses and in-house standards. These limits

134 apply at, or greater than, fifty times the limit of detection.

135 Results

136 Field Observations and Petrography

The Pele dykes range from $5 \mathrm{~m}$ to $20 \mathrm{~m}$ wide (Fig. 2) and are composed of a medium

138 grained grey to light green rock that is almost, but not entirely free of inclusions (Figs. 3A and

139 3B). It is notable that no inclusion-rich quartz diorite was found in the centre of any of the Pele

140 dykes. Clasts of the coarse-grained Cartier granite host rock can, however, be found close to the

141 dyke margins (Fig. 3B). These clasts are up to $\sim 10 \mathrm{~cm}$ long, oriented parallel to the dyke

142 margins, and occur along with smaller sub-rounded mineral clasts of plagioclase and quartz (Fig.

143 3B). 

grained pale to deep green amphiboles $(30-40 \%)$, platy biotite $(\sim 25 \%)$, coarse grained euhedral plagioclase laths $(\sim 10 \%)$ and fine- to medium-grained quartz $(\sim 5 \%)$, set in a groundmass of

147 granophyric intergrowths of quartz (15-25\%) and K-feldspar ( $5 \%$ ) (Figs. 3C and 3D). Many of 148 the samples display varying degrees of alteration, including pervasive epidote alteration in places 149 (Fig. 3C), the occasional carbonate- and sericite-bearing veinlet (Fig. 3E), and chloritization of 150 amphiboles (Figs. 3D and 3F). Samples contain trace amounts of anhedral pyrite and chalcopyrite, typically $<20 \mu \mathrm{m}$ in size. Samples of the Western dyke contain higher proportions 152 of amphibole (40-50\%), along with plagioclase ( 20\%), quartz (10-15\%), biotite (10-15\%), 153 and magnetite with exsolution of ilmenite ( $\sim \%)$ (Fig. 3F). Plagioclase within the Pele dykes is 154 commonly intergrown with quartz or occurs as tabular euhedral crystals, and is very sodic in 155 composition, varying from albite to oligioclase (Table 1). Samples of the Western dyke contain 156 higher proportions of subhedral pyrite and chalcopyrite, up to $\sim 2 \%$. Accessory minerals in all 157 three Pele dykes include magnetite with lamellar exsolutions of ilmenite, apatite, chlorite, and 158 zircon.

\section{Geochemistry}

Representative geochemical analyses from the Pele dykes are reported in Table 2. When the Pele dyke samples' CIPW normative mineralogies are plotted on a QAP diagram (Fig. 4), the

162 Central and Eastern dykes would be classified as a granodiorite and the Western dyke would be 163 classified as a quartz monzodiorite. For the Central and Eastern dykes, the average contents of $164 \mathrm{SiO}_{2}, \mathrm{Fe}_{2} \mathrm{O}_{3}$, and $\mathrm{CaO}$ are 60.6 wt. \%, 10.1 wt. \%, and 5.3 wt. \%, respectively (Table 2). By 165 comparison, the Western dyke is more mafic, with average contents of $\mathrm{SiO}_{2}, \mathrm{Fe}_{2} \mathrm{O}_{3}$, and $\mathrm{CaO}$ of 54.9 wt. \%, 13.9 wt. \%, and 5.2 wt. \%, respectively (Table 2). The Central and Eastern dykes 
167 have a very low average $\mathrm{Mg} \#$ of 15 and the Western dyke has an average $\mathrm{Mg} \#$ of 23 . By

168 comparison, the Foy dyke has an average Mg \# of 32 (Tuchscherer 1998), while the Granophyre 169 unit of the SIC has an average Mg \# of 13 (Therriault et al. 2002). This difference in magnesium 170 content is highlighted in Figures 5A and 5B, which shows how the Pele quartz diorite dykes are 171 enriched in $\mathrm{SiO}_{2}$ and $\mathrm{TiO}_{2}$ and depleted in $\mathrm{MgO}$ relative to the SIC or the Foy dyke. The Central 172 and Eastern dykes also have very low sulfur contents, below 0.05 wt. \%; whereas, the Western 173 dyke contains up to 0.25 wt. \% sulfur (Table 2) and the Foy dyke has an average sulfur content 174 of 0.13 wt. $\%(n=13$, Lightfoot et al., 1997). There are several differences in trace element ratios and abundances between the Pele 176 dykes. The Central and Eastern dykes typically have higher $\mathrm{La} / \mathrm{Nb}, \mathrm{La} / \mathrm{Sm}, \mathrm{Th} / \mathrm{Zr}$, and $\mathrm{Sr} / \mathrm{Y}$ 177 ratios compared to the Western dyke (Figs. 5C and 5D). The Central and Eastern dykes are 178 particularly enriched in incompatible trace elements compared to the Western dyke (Table 2).

179 This can be seen in Figure 6, which plots average incompatible trace element compositions from 180 the Pele dykes and the Granophyre and Norite units of the SIC as spider diagrams normalized to the average Foy dyke (Tuchscherer 1998). The Central and Eastern dykes (Figs. 7A and 7B) are 182 also enriched in both light and heavy rare earth elements (REE), relative to the Western dyke 183 (Fig. 7C).

The Pele Offset Dykes have a very similar appearance in the field to some of the

185 Nipissing Diabase dykes in the region. The Nipissing Diabase samples, however, are easily 186 distinguished by their chemistry and the plagioclase within the Nipissing diabase samples is 187 typically very blocky in shape and is very calcium rich, varying from labradorite to bytownite 188 (Table 1). For example, the Nipissing Diabase samples are more mafic than the Pele Offset 189 Dykes, and have average contents of $\mathrm{SiO}_{2}, \mathrm{Fe}_{2} \mathrm{O}_{3}$, and $\mathrm{CaO}$ of 49.9 wt. \%, 12.4 wt. \%, and 9.7 
190 wt. \%, respectively (Table 2), and have an average Mg \# of 38 . When compared to the Pele

191 Offset Dykes, the Nipissing Diabase samples also have much lower La/Nb and Th/Zr ratios (Fig.

192 5C) and are very depleted in light rare earth elements (LREE) (Figs. 7A and 7B).

\section{Discussion}

\section{Field Relationships and Mineralogy}

The Pele Offset Dykes are much narrower (5-20 m) than most other radial Offset Dykes,

196 which commonly reach thicknesses of up to $100 \mathrm{~m}$ (e.g., Murphy and Spray 2002; Tuchscherer 197 1998). The Pele dykes, however, are comparable in width to the Trill Offset Dyke, which is, in 198 places, only 3-20 m wide (Coulter 2015). Additionally, the Pele Offset Dykes do not contain an 199 "exotic" inclusion-rich phase (Fig. 3). The only clasts visible in the Pele Offset Dykes are the occasional rip-up clasts from the host rock along the margins of the dyke (e.g., Fig. 3B). This is

201 significant, as all other known Offset Dykes consist of both an inclusion-poor and an inclusion202 rich phase (Grant and Bite 1984; Lightfoot et al. 1997). The distal portions of some Offset 203 Dykes, such as the Foy and Trill, have been known to consist only of the inclusion-poor phase, 204 and are also very thin, only 10-20 m (Murphy and Spray 2002; Tuchscherer 1998; Coulter 205 2015), however, inclusions are common at other sections of these dykes. Considering that the 206 Pele dykes contain no inclusion-rich phase, the dykes were likely intruded from a portion of the 207 SIC that was barren in clasts at the time.

The CIPW normative mineralogy of the samples from the Central and Eastern dykes is 209 granodiorite; whereas, the Western dyke would be considered a quartz monzodiorite (Fig. 4).

210 The samples are composed predominantly of amphibole, biotite, plagioclase, and granophyric 211 intergrowths of quartz and K-feldspar (Fig. 3). This mineralogy is quite typical among the other 
212 Offset Dykes, such as the Foy, Parkin, Hess and Trill dykes (e.g., Tuchscherer 1998; Wood 213 1998; Murphy and Spray 2002; Coulter 2015). The Pele Offset Dykes, however, do contain a 214 higher proportion of granophyric intergrowths than the other Offset Dykes and, in addition, the

215 Western dyke contains a higher proportion of amphibole, pyrite, magnetite, and ilmenite.

216 Samples from the Western dyke typically display higher degrees of hydrothermal alteration, 217 compared to Pele East. This is reflected in thin section by a higher abundance of epidotization 218 and chloritization (Figs. 3C and 3D).

\section{Chemical Variation}

Cross-cutting relationships between the Western, Central, and Eastern Pele dykes are not observable in the field. As a result, an attempt is made to interpret their temporal relationship by comparing the chemical compositions of the Pele dykes to their source, the SIC. It is generally believed that the SIC formed from crystal differentiation of a largely homogenous impact melt by orthopyroxene and plagioclase crystallization, and the crystallization of the residual melt from 225 the base-up and the top-down (e.g., Naldrett and Hewins 1984; Grieve et al. 1991; Warner et al. 1998; Lightfoot et al. 1997; Lightfoot et al. 2001; Therriault et al. 2002, etc.). If this working

227 hypothesis is correct, Offset Dykes emplaced later (relative to the differentiation of the SIC)

228 would have a more evolved chemical composition. As there are known chemical and 229 mineralogical differences between the North and South Ranges of the SIC (see Lightfoot 2016 230 and references therein), data from the SIC for this comparison is taken from Therriault et al. 231 (2002), whose data for the composition of the SIC are from three drill cores in the North Range. 
235 is particularly evident in Figures 5C and 5D, which plot data from the Pele dykes in comparison 236 to the Norite and Granophyre units of the SIC and the Foy Offset Dyke. The Pele dykes have $237 \mathrm{La} / \mathrm{Nb}, \mathrm{Th} / \mathrm{Zr}$, and $\mathrm{La} / \mathrm{Sm}$ ratios nearly identical to those from the SIC (Figs. 5C and 5D) and a $238 \mathrm{Sr} / \mathrm{Y}$ ratio that falls roughly between that of the Granophyre and Norite units of the SIC (Fig. 239 5D). Additionally, Dy/Dy* ratios (the measured value of Dy compared with the value 240 interpolated between La and $\mathrm{Yb}$ ) were calculated using (see Davidson et al. 2013; Fig. 5E). The 241 242 243 244 Dy/Dy* value measures the concavity of a REE. Davidson et al. (2013) found that in suites of samples from a single volcano Dy/Dy* and $\mathrm{Dy} / \mathrm{Yb}$ decrease with differentiation. The Pele dykes fall along the trendline defined by the samples from the SIC in figure 5E. The Western Pele dyke has slightly higher Dy/Dy* and Dy/Yb values than the Central or Eastern Pele dykes. This indicates that if the three Pele dykes originated from the same source, the Central and Eastern dykes represent the more chemically evolved end of the spectrum. These observations suggest 247 that, while the Pele dykes may have a unique chemistry in terms of major element oxides 248 compared to other Offset Dykes, they are related to the SIC and are a part of the Offset Dyke system. This is consistent with their age of $1848.5 \pm 0.8$ (Bleeker et al. 2015), which is 250 indistinguishable from the age of the SIC (Davis 2008).

The Central and Eastern Pele dykes have a more evolved chemical composition than the other Offset Dykes. They are enriched in $\mathrm{SiO}_{2}$ (Fig. 4), and have a lower $\mathrm{Mg} \#$ (average of 15) compared to the other Offset Dykes, such as the Foy dyke, which has an average Mg \# of 32

254 (Tuchscherer 1998). The Central and Eastern Pele dykes are enriched in incompatible elements 255 relative to the Norite, with abundances similar to that of the Granophyre unit of the SIC (Fig. 6). 256 Similarly, Tuchscherer (1998) observed that the Pele dyke was enriched in REE relative to the 257 Foy dyke, and Smith et al. (2013) observed that the Pele dykes have similar textures and 
258 compositions to the upper Granophyre of the SIC. While our results are consistent with these 259 previous observations, it is important to note that the Granophyre has undergone pervasive 260 metasomatism (Stewart 2017), which has altered its primary chemistry. Therefore, while our 261 results show that the Central and Eastern Pele dykes have a more evolved chemistry when 262 compared to the other Offset Dykes, their relationship with the Granophyre unit of the SIC 263 remains uncertain.

If the SIC differentiated via fractional crystallization, then the more-evolved chemistry of 265 the Central and Eastern Pele dykes suggest that the Pele dykes were intruded later than the other 266 North Range Offset Dykes, relative to the differentiation of the SIC. This would suggest that the 267 Central and Eastern Pele dykes may be examples of the last known Offset Dykes to be 268 emplaced, relative to the fractional crystallization of the SIC. This is consistent with the lack of 269 the IQD phase as discussed above. In other words, any clasts had either sunk or been assimilated 270 in their source region of the SIC by the time the Pele dykes were intruded. By comparison, the Western Pele dyke has a more mafic chemical composition (Figs. 4, $2725 \mathrm{~A}$, and 5B) and a higher average $\mathrm{Mg} \#$ of 23 due to its higher amphibole content. While it is 273 possible that the Western Pele dyke could have been emplaced from a more mafic portion of the 274 SIC melt, it is unlikely that the dykes tapped from different sources of the SIC given their 275 proximity. What is more likely is that the Pele dykes were emplaced at different times 276 throughout the differentiation history of the SIC. This is supported by the elevated Dy/Dy* ratios 277 in the Western dyke relative to the Central and Eastern dykes (Fig. 5E). The Western dyke also 278 have higher sulfur and nickel contents due to the dyke's higher sulfide content. The Western 279 dyke is also depleted in REE relative to the Central and Eastern dykes (Figs. 6 and 7). These 280 observations suggest that the Western dyke has a less evolved chemical composition than the 
281 Central or Eastern dykes. These observations suggest that the Pele Offset Dyke system was

282

283

284

285

286

287

288

289

290

291

292

293

294

295

296

297

298

299

300

301

302

303

emplaced during two separate injection events: an early emplacement of a relatively more

sulfide-rich quartz monzodiorite melt that formed the Western dyke, and a later emplacement of sulfide-poor granodiorite melt that formed the Central and Eastern dykes.

Results herein suggest that the three Pele dykes are a part of the Offset Dyke system, and likely originated from the SIC. Given the chemically evolved nature of the Central and Eastern dykes (i.e., granodiorite melt, Fig. 4), we believe that these two Pele dykes may have been emplaced at some point during the differentiation of the SIC, and tapped from a more chemically-evolved SIC melt. To test the hypothesis that the Pele dykes were emplaced during two separate intrusive events, principal component analysis was used to compare groups of correlated variables between the three dykes.

\section{Principal Component Analysis}

The chemical variations between the Pele dykes and the SIC are clearest displayed when examining multiple geochemical variables. To compare multiple variables at once, principal components analysis can be used to transform a group of correlated variables (e.g., the major element oxides), such that the first few components account for a large proportion of the variance of the original data set (Jolliffe 2014). For this study, robust principal component analysis (RPC) was used to correct for the effect of outliers (Campbell 1980), and the covariance (i.e., the variance between the variables) was calculated by weighting each of the samples by their robustly estimated Mahalanobis distance (Maronna 1976; De Maesschalck et al. 2000). The first principal component (RPC1) defines the maximum variation through the cluster, and the second principal component (RPC2) defines the maximum spread at right angles to RPC1, and so on when many variables are considered. Thus, the majority of variability in the original dataset can 
304 be plotted by examining RPC1 versus RPC2. Robust principal component analysis was

305 calculated using the program ioGAS version 6.1 for the Pele dykes, the different units of the SIC

306 (data from Therriault et al. 2002) and the Foy Offset Dyke (data from Wallbridge Mining

307 Company Limited).

The chemical variations between the Pele dykes and the units of the SIC are highlighted

309

310

311

312

313

314

315

316

317

318

319

320

321

322

323

324

325

326

in Figure 8, which uses robust principal component analysis (RPC) to calculate the variation between the major oxides (Fig. 8A) and immobile elements (Fig. 8B). Data is depicted as Mahalanobis ellipses for the Granophyre and Norite units of the SIC, and the Foy Offset Dyke. The Central and Eastern Pele dykes have $\mathrm{CaO}, \mathrm{MgO}, \mathrm{SiO}_{2}, \mathrm{~K}_{2} \mathrm{O}$, and $\mathrm{Na}_{2} \mathrm{O}$ values that fall between that of the Norite and Granophyre units of the SIC, but are enriched in $\mathrm{Fe}_{2} \mathrm{O}_{3}, \mathrm{P}_{2} \mathrm{O}_{5}$, and $\mathrm{TiO}_{2}$ (Fig. 8A). The Central and Eastern dykes also have immobile element compositions similar to the Granophyre unit of the SIC, but with elevated $\mathrm{TiO}_{2}$ and $\mathrm{Y}$ (Fig. 8B). By comparison, the Western dyke is more mafic in composition, comparable to the Norite unit of the SIC (Fig. 8A), but again with elevated $\mathrm{Fe}_{2} \mathrm{O}_{3}, \mathrm{P}_{2} \mathrm{O}_{5}$, and $\mathrm{TiO}_{2}$ values (Fig. 8A). The Western dyke is also depleted in immobile elements relative to the Central and Eastern dykes (Fig. 8B). This demonstrates that the three Pele dykes have a more evolved chemical composition than the other Offset Dykes such as the Foy. Furthermore, the Central and Eastern dykes are more evolved than the Western dyke, which suggests the Pele dyke system was emplaced during two intrusive events: a more primitive (i.e., quartz monzodiorite melt, Fig. 4) sulfide-bearing melt that formed the Western dyke, followed by intrusion of a more chemically evolved (i.e., granodiorite melt, Fig. 4) that formed the Central and Eastern dykes.

The exact timing of formation of the Pele dykes - in the context of the other Offset Dykes and the SIC - remain uncertain. It is generally believed that the inclusion- and sulfide- 
327 poor QD was emplaced shortly after the formation of the superheated impact melt sheet (see

328 Lightfoot 2016 and references therein). This was followed by sulfide saturation of the impact

329 melt sheet and emplacement of the sulfide-rich IQD. After formation of the Offset Dykes,

330 differentiation and crystallization of the SIC occurred. Results herein suggest that the Central and

331 Eastern Pele dykes were emplaced from a more chemically evolved SIC melt, however, at this

332 time, no Offset Dykes have been observed to cross-cut the SIC itself. Furthermore, if the

333 Western dyke was emplaced earlier than the Central and Eastern dykes, why does it also lack an

334 inclusion-bearing quartz diorite phase - as is observed at every other Offset Dyke? Although

335 these questions remain uncertain, several conclusions can be drawn regarding the composition of

336 these unique Offset Dykes.

\section{Concluding Remarks}

1. Field observations and petrography of the Pele Offset Dykes are generally consistent with previous findings by Tuchscherer (1998) and Bleeker et al. (2015), which were based on one sample each. The mineralogy of the Pele dykes consists of amphiboles, biotite, granophyric intergrowths of quartz and K-feldspar, plagioclase, and quartz. The Pele Offset Dykes typically have much higher proportions of granophyric intergrowths and are enriched in magnetite and ilmenite compared to other Offset Dykes.

2. When compared to the Foy Offset Dyke, the Pele dykes have a more evolved chemical composition, being considerably more felsic and enriched in incompatible elements. If one considers a simple uniform fractionating melt sheet, these observations, along with age dating by Bleeker et al. (2015), suggest that, although the Pele Offset Dykes are a 
part of the Offset Dyke system, they may have been one of the last known Offset Dykes to have been emplaced, relative to the differentiation of the SIC.

3. The Western dyke - when compared to the Central or Eastern dykes - is more mafic, has higher rare earth and immobile element compositions, has higher Dy/Dy* and Dy/Yb ratios, and is sulfide-bearing. This suggests that the Western dyke is less evolved than the Central and Eastern dykes, and was likely emplaced earlier, relative to the differentiation of the SIC (again, given a simple uniform fractionating melt sheet).

4. The Pele Offset Dykes do not have an inclusion-rich phase, which suggests that the Pele dykes were emplaced from a portion of the SIC that was barren in clasts at the time of intrusion.

\section{Acknowledgements}

Attila Pentek, Jian Xiong, and the staff at Wallbridge Mining Company Limited for their continued support and access to property and samples. The Centre for Excellence in Mining Innovation is thanked for their support. Nicola Barry, Sean Israelson, and Scott Hutchinson are thanked for their assistance in the field. This work was funded by an NSERC Collaborative Research and Development grant, a Mitacs Accelerate Graduate Research Internship, and an Ontario Centres of Excellence (OCE), Collaborate to Commercialize grant.

\section{References}

Ames D.E., Davidson A., and Wodicka N. 2008. Geology of the Giant Sudbury Polymetallic Mining Camp, Ontario, Canada. Economic Geology, 103: 1057-1077.

Anders, D.A., Osinski, G.R., Grieve, R.A.F., and Brillinger, D.T.M. 2015. The Upper Contact Unit in the North Range: Roof rocks of the Sudbury Igneous Complex. Meteoritics and Planetary Science, 50: 1577-1594.Bleeker, W., Kamo, S.L., Ames, D.E., and Davis, D. 2015. New field observations and U-Pb ages in the Sudbury area: toward a detailed crosssection through the deformed Sudbury Structure. In Targeted Geoscience Initiative 4: 
Canadian Nickel-Copper- Platinum Group Elements-Chromium Ore Systems - Fertility, Pathfinders, New and Revised Models. Edited by D.E. Ames and M.G. Houlé. Geological Survey of Canada, Open File 7856, pp. 151-166.

Campbell, N.A. 1980. Robust procedures in multivariate analysis. I: Robust covariance estimation. Journal of Applied Statistics, 29: 231-237.

Corfu, F., and Andrews, A. 1986. A U-Pb age for mineralized Nipissing diabase, Gowganda, Ontario. Canadian Journal of Earth Sciences, 23: 107-112.

Coulter, A.B. 2015. The underlying structural controls of the Whistle-Parkin and Trill Offset Dykes in the Sudbury Impact Structure. M.Sc. thesis, Department of Earth Sciences, University of Western Ontario, Ontario, Canada.

Davidson, J., Turner, S., Plank, T. 2013. Dy/Dy*: variations arising from mantle source and petrogenetic processes. Journal of Petrology, 54: 525-537.

Davis D.W. 2008. Sub-million-year age resolution of Precambrian igneous events by thermal extraction-thermal ionization mass spectrometer $\mathrm{Pb}$ dating of zircon: Application to crystallization of the Sudbury impact melt sheet. Geology, 36: 383-386.

De Maesschalck, R., Jouan-Rimbaud, D., and Massart, D.L. 2000. The Mahalanobis distance. Chemometrics and Intelligent Laboratory Systems, 50: 1-18.

Dressler, B.O. 1982. Geology of the Wanapitei Lake area, district of Sudbury. Ontario Geological Survey, Report 213, pp. 131. Accompanied by Maps 2450 and 2451, scale $1: 31680$ or 1 inch to $1 / 2$ mile.

Grant, R.W., and Bite, A. 1984. Sudbury quartz diorite offset dykes. In The Geology and Ore Deposits of the Sudbury Structure. Edited by E.G. Pye, A.J. Naldrett and P.E. Giblin. Ontario Geological Survey Special Volume 1, Ministry Natural Resources, Toronto. pp. 275-300.

Grieve, R.A.F., Stöffler, D., and Deutsch, A. 1991. The Sudbury Structure: Controversial or Misunderstood? Journal of Geophysical Research, 96: 22,753-22,764.

Grieve, R.A.F., Reimold, W.U., Morgan, J., Riller, U., and Pilkington, M. 2008. Observations and interpretations at Vredefort, Sudbury, and Chicxulub: Towards an empirical model of terrestrial impact basin formation. Meteoritics \& Planetary Science, 43: 855-882.

Jolliffe, I. 2014. Principal Component Analysis. Wiley StatsRef: Statistics Reference Online.

Kelley, K.A., Plank, T., Ludden, J., Staudigel, H. 2003. Composition of altered oceanic crust at ODP Sites 801 and 1149. Geochemistry, Geophysics, Geosystems, 4.

Lightfoot, P.C. 2016. Nickel Sulfide Ores and Impact Melts. Elsevier, p. 680.

Lightfoot, P.C., and Farrow, C.E.G. 2002. Geology, geochemistry, and mineralogy of the Worthington Offset Dyke: A genetic model for Offset Dyke mineralization in the Sudbury Igneous Complex. Economic Geology, 97: 1419-1446.Lightfoot, P.C., Keays, R.R., Morrison, G.C., Bite, A., and Farrell, K.P. 1997. Geochemical relationships in the Sudbury Igneous Complex: Origin of the Main Mass and Offset Dykes. Economic Geology, 92: 299-307. 
Lightfoot, P.C., Keays, R.R., and Doherty, W. 2001. Chemical Evolution and Origin of Nickel Sulfide Mineralization in the Sudbury Igneous complex, Ontario, Canada. Economic Geology, 96: 1855-1875

Maronna, R.A. 1976. Robust M-estimators of multivariate location and scatter. Analytical Statistics, 1: 51-67.

Murphy, A.J., and Spray, J.G. 2002. Geology, Mineralization, and Emplacement of the WhistleParkin Offset Dyke, Sudbury. Economic Geology, 97: 1399-1418.

Nakamura N. 1974. Determination of REE, Ba, Fe, Mg, $\mathrm{Na}$ and $\mathrm{K}$ in carbonaceous and ordinary chondrites. Geochimica et Cosmochimica Acta, 38: 757-775.

Naldrett, A.J. and Hewins, R.H., 1984. The main mass of the Sudbury Igneous Complex. In The Geology and Ore Deposits of the Sudbury Structure. Edited by E.G. Pye, A.J. Naldrett and P.E. Giblin. Ontario Geological Survey Special Volume 1, Ministry Natural Resources, Toronto. pp. 235-252.

Naldrett, A.J., Bray, J.G., Gasparrini, E.L., Podolsky, T., and Rucklidge, J. D. 1970. Cryptic variation and the petrology of the Sudbury Nickel Irruptive. Economic Geology, 65: 122155.Ontario Geological Survey August 2003. 1:250,000-scale Bedrock Geology of Ontario. Ontario Geological Survey, Miscellaneous Release-Data 126.

Pilles, E.A., Osinski, G.R., Grieve, R.A.F., Smith, D., and Bailey, J. 2017. Chemical variations and genetic relationships between the Hess and the Foy Offset Dikes at the Sudbury impact structure. Meteoritics and Planetary Science. doi:10.1111/maps.12986Rousell, D.H., Fedorowich, J.S., and Dressler, B.O. 2003. Sudbury Breccia (Canada): a product of the $1850 \mathrm{Ma}$ Sudbury Event and host to footwall Cu-Ni-PGE deposits. Earth-Science Reviews, 60: 147-174.

Smith, D.A., Bailey, J., and Pattison, E.F. 2013. Discovery of new Offset Dykes and insights into the Sudbury impact structure (abstract). In LPI Contributions 1737, p. 3090.

Stewart, R.C. 2017. Characterization of barren and mineralized hydrothermal systems in an impact structure: the granophyre unit and footwall of the Sudbury Igneous Complex, Ontario, Canada. Ph.D. thesis, Department of Mineral Deposits and Precambrian Geology, Laurentian University, Sudbury, Canada.

Streckeisen, A. 1976. To each plutonic rock its proper name. Earth Science Reviews, 12: 1-33.

Therriault, A.M., Fowler, A.D., and Grieve, R.A.F. 2002. The Sudbury Igneous Complex: A differentiated impact melt sheet. Economic Geology, 97: 1521-1540.

Tuchscherer, M.G. 1998. The petrology, geochemistry, and emplacement of the Foy Offset Dyke, Sudbury impact structure. M.Sc. thesis, Department of Earth Sciences, University of New Brunswick, New Brunswick, Canada.

Tuchscherer, M.G., and Spray, J. 2002. Geology, mineralization, and emplacement of the Foy Offset Dyke, Sudbury impact structure. Economic Geology, 97: 1377-1397.

Warner, S., Martin, R.F., Abdel-Rahman, A.M., and Doig, R. 1998. Apatite as a monitor of fractionation, degassing, and metamorphism in the Sudbury igneous complex, Ontario. Canadian Mineralogist, 36:981-1000. 
452 Wood, C.R. 1998. Origin and emplacement of the Hess Offset Dyke, north range of the Sudbury 453 impact structure. M.Sc. thesis, Department of Earth Sciences, University of New $454 \quad$ Brunswick, New Brunswick, Canada. 


\section{Tables}

456 Table 1. Representative electron microprobe analyses of plagioclase from the matrix of the Pele 457 dykes reported as means with standard deviation given in parenthesis.

\begin{tabular}{llrrrrrrrr}
\hline Sample & Dyke & $\begin{array}{r}\mathrm{An} \\
(\text { Mole \%) }\end{array}$ & $\begin{array}{r}\mathrm{SiO}_{2} \\
(\mathrm{Wt} . \%)\end{array}$ & $\begin{array}{r}\mathrm{Al}_{2} \mathrm{O}_{3} \\
(\mathrm{Wt.} \%)\end{array}$ & $\begin{array}{r}\mathrm{Na}_{2} \mathrm{O} \\
(\mathrm{Wt} . \%)\end{array}$ & $\begin{array}{r}\mathrm{MgO} \\
(\text { Wt. \%) }\end{array}$ & $\begin{array}{r}\mathrm{TiO}_{2} \\
(\text { Wt. \%) }\end{array}$ & $\begin{array}{r}\mathrm{CaO} \\
(\text { Wt. \%) }\end{array}$ & $\begin{array}{r}\mathrm{K}_{2} \mathrm{O} \\
(\text { Wt. \%) }\end{array}$ \\
\hline 809930 & West Pele & 10.71 & 67.2 & 21.21 & 11.11 & 0.01 & 0.02 & 1.25 & 0.05 \\
$(\mathrm{n}=16)$ & Dyke & $( \pm 8.15)$ & $( \pm 1.38)$ & $( \pm 0.79)$ & $( \pm 0.65)$ & $( \pm 0.01)$ & $( \pm 0.02)$ & $( \pm 1.06)$ & $( \pm 0.01)$ \\
809963 & West Pele & 5.69 & 67.79 & 20.83 & 11.37 & 0.01 & 0.02 & 0.65 & 0.06 \\
$(\mathrm{n}=16)$ & Dyke & $( \pm 6.45)$ & $( \pm 1.03)$ & $( \pm 0.75)$ & $( \pm 0.43)$ & $( \pm 0.01)$ & $( \pm 0.01)$ & $( \pm 0.76)$ & $( \pm 0.01)$ \\
703829 & Centre Pele & 8.07 & 67.63 & 20.71 & 11.28 & 0.03 & 0.01 & 0.92 & 0.05 \\
$(\mathrm{n}=16)$ & Dyke & $( \pm 6.26)$ & $( \pm 0.94)$ & $( \pm 0.69)$ & $( \pm 0.47)$ & $( \pm 0.06)$ & $( \pm 0.01)$ & $( \pm 0.75)$ & $( \pm 0.01)$ \\
$\mathrm{SI}-013$ & Centre Pele & 2.76 & 68.28 & 19.97 & 11.6 & 0.01 & 0.04 & 0.3 & 0.06 \\
$(\mathrm{n}=14)$ & Dyke & $( \pm 0.95)$ & $( \pm 0.57)$ & $( \pm 0.27)$ & $( \pm 0.26)$ & $( \pm 0.01)$ & $( \pm 0.03)$ & $( \pm 0.1)$ & $( \pm 0.01)$ \\
$\mathrm{SI}-005$ & & 71.75 & 53.8 & 29.08 & 4.95 & 0.07 & 0.03 & 11.49 & 0.11 \\
$(\mathrm{n}=16)$ & Diabase & $( \pm 5.12)$ & $( \pm 1.46)$ & $( \pm 0.96)$ & $( \pm 0.69)$ & $( \pm 0.03)$ & $( \pm 0.02)$ & $( \pm 1.22)$ & $( \pm 0.05)$ \\
$\mathrm{SI}-010$ & & 69.34 & 54.23 & 28.9 & 5.21 & 0.08 & 0.03 & 10.8 & 0.13 \\
$(\mathrm{n}=12)$ & Diabase & $( \pm 6.58)$ & $( \pm 1.98)$ & $( \pm 1.22)$ & $( \pm 0.88)$ & $( \pm 0.04)$ & $( \pm 0.01)$ & $( \pm 1.44)$ & $( \pm 0.05)$ \\
\hline
\end{tabular}

\begin{tabular}{llrrrrrrr}
\hline & & $\begin{array}{r}\mathrm{FeO} \\
\text { St. \%) }\end{array}$ & $\begin{array}{r}\mathrm{MnO} \\
(\text { Wt. \%) }\end{array}$ & $\begin{array}{r}\mathrm{Cr}_{2} \mathrm{O}_{3} \\
(\text { (Wt. \%) }\end{array}$ & $\begin{array}{r}\mathrm{BaO} \\
(\text { Wt. \%) }\end{array}$ & $\begin{array}{r}\mathrm{SrO} \\
(\text { Wt. \%) }\end{array}$ & $\begin{array}{r}\mathrm{Eu}_{2} \mathrm{O}_{3} \\
(\text { Wt. \%) }\end{array}$ & $\begin{array}{r}\text { Total } \\
(\text { Wt. \%) }\end{array}$ \\
\hline 809930 & West Pele & 0.31 & 0.01 & 0.007 & 0.016 & 0.109 & 0.02 & 101.29 \\
$(\mathrm{n}=16)$ & Dyke & $( \pm 0.07)$ & $( \pm 0.01)$ & $( \pm 0.006)$ & $( \pm 0.009)$ & $( \pm 0.056)$ & $( \pm 0.01)$ & $( \pm 0.27)$ \\
809963 & West Pele & 0.16 & 0.01 & 0.01 & 0.038 & 0.056 & 0.03 & 100.97 \\
$(\mathrm{n}=16)$ & Dyke & $( \pm 0.08)$ & $( \pm 0.01)$ & $( \pm 0.006)$ & $( \pm 0.043)$ & $( \pm 0.036)$ & $( \pm 0.023)$ & $( \pm 0.32)$ \\
703829 & Centre Pele & 0.15 & 0.01 & 0.01 & 0.011 & 0.034 & 0.03 & 100.84 \\
$(\mathrm{n}=16)$ & Dyke & $( \pm 0.06)$ & $( \pm 0.01)$ & $( \pm 0.007)$ & $( \pm 0.007)$ & $( \pm 0.019)$ & $( \pm 0.021)$ & $( \pm 0.4)$ \\
SI-013 & Centre Pele & 0.28 & 0.01 & 0.013 & 0.021 & 0.039 & 0.019 & 100.57 \\
$(\mathrm{n}=14)$ & Dyke & $( \pm 0.11)$ & $( \pm 0.01)$ & $( \pm 0.009)$ & $( \pm 0.014)$ & $( \pm 0.019)$ & $( \pm 0.01)$ & $( \pm 1.02)$ \\
$\mathrm{SI}-005$ & & 0.69 & 0.01 & 0.011 & 0.025 & 0.044 & 0.016 & 100.28 \\
$(\mathrm{n}=16)$ & Diabase & $( \pm 0.19)$ & $( \pm 0.01)$ & $( \pm 0.005)$ & $( \pm 0.019)$ & $( \pm 0.025)$ & $( \pm 0.01)$ & $( \pm 0.23)$ \\
$\mathrm{SI}-010$ & & 0.72 & 0.01 & 0.006 & 0.019 & 0.055 & 0.013 & 100.17 \\
$(\mathrm{n}=12)$ & Diabase & $( \pm 0.29)$ & $( \pm 0.01)$ & $( \pm 0.004)$ & $( \pm 0.014)$ & $( \pm 0.027)$ & $( \pm 0.008)$ & $( \pm 0.23)$ \\
\hline
\end{tabular}


460 Table 2. Representative geochemistry of the Pele Offset Dykes. Coordinates reported in NAD83.

461 b.d.l. = below detection limit; n.d. = no data. Lower limits of detection are reported in

462 parentheses.

\begin{tabular}{|c|c|c|c|c|c|c|c|c|c|c|}
\hline & \multicolumn{3}{|c|}{ Nipissing Diabase } & \multicolumn{3}{|c|}{ Western Pele Dyke } & \multicolumn{3}{|c|}{ Central Pele Dyke } & \multirow{2}{*}{$\begin{array}{r}\begin{array}{c}\text { Eastern } \\
\text { Pele Dyke }\end{array} \\
604275\end{array}$} \\
\hline & 120501 & SI-005 & SI-011 & 809926 & 809954 & 809957 & 604356 & 703828 & 703847 & \\
\hline & 476752 & 476734 & 476162 & 474894 & 474590 & 474497 & 476154 & 476053 & 475825 & 476489 \\
\hline & 5179554 & 5179594 & 5178231 & 5180877 & 5181408 & 5181745 & 5178071 & 5179287 & 5181144 & 5180762 \\
\hline & \multicolumn{10}{|c|}{ Major Oxide (weight \%) } \\
\hline $\mathrm{SiO}_{2}(0.01)$ & 50.20 & 50.00 & 52.60 & 56.50 & 56.40 & 55.30 & 62.10 & 63.20 & 64.60 & 62.90 \\
\hline $\mathrm{Al}_{2} \mathrm{O}_{3}(0.01)$ & 13.40 & 15.50 & 13.20 & 12.60 & 12.80 & 12.40 & 13.20 & 13.20 & 12.20 & 12.60 \\
\hline $\mathrm{Fe}_{2} \mathrm{O}_{3}(0.01)$ & 14.15 & 12.50 & 15.00 & 13.60 & 13.95 & 14.50 & 9.40 & 9.10 & 9.30 & 8.70 \\
\hline $\mathrm{CaO}(0.01)$ & 9.83 & 10.80 & 8.73 & 6.19 & 5.74 & 4.59 & 4.40 & 3.90 & 4.10 & 4.90 \\
\hline $\mathrm{MgO}(0.01)$ & 6.18 & 5.68 & 5.24 & 2.82 & 2.87 & 4.39 & 1.50 & 1.50 & 1.30 & 1.40 \\
\hline $\mathrm{Na}_{2} \mathrm{O}(0.01)$ & 2.13 & 2.16 & 2.54 & 3.32 & 3.78 & 3.95 & 3.40 & 3.20 & 3.00 & 3.20 \\
\hline $\mathrm{K}_{2} \mathrm{O}(0.01)$ & 0.85 & 0.62 & 0.86 & 1.61 & 1.63 & 1.27 & 2.70 & 2.70 & 2.50 & 2.70 \\
\hline $\mathrm{TiO}_{2}(0.01)$ & 0.97 & 1.00 & 1.25 & 1.70 & 1.72 & 1.68 & 1.60 & 1.50 & 1.60 & 1.50 \\
\hline $\mathrm{MnO}(0.01)$ & 0.21 & 0.20 & 0.26 & 0.19 & 0.19 & 0.23 & 0.20 & 0.20 & 0.10 & 0.10 \\
\hline $\mathrm{P}_{2} \mathrm{O}_{5}(0.01)$ & 0.09 & 0.08 & 0.15 & 0.40 & 0.40 & 0.39 & 0.50 & 0.50 & 0.40 & 0.50 \\
\hline $\mathrm{BaO}(0.01)$ & 0.02 & 0.02 & 0.03 & 0.05 & 0.07 & 0.06 & 0.10 & 0.10 & 0.10 & 0.10 \\
\hline $\mathrm{S}(0.01)$ & 0.04 & 0.06 & 0.05 & 0.09 & 0.10 & 0.25 & 0.10 & 0.10 & b.d.l. & b.d.1. \\
\hline Total & 98.11 & 98.66 & 99.93 & 99.13 & 99.70 & 99.03 & 99.20 & 99.30 & 99.40 & 98.70 \\
\hline \multirow[t]{2}{*}{ Mg number } & 46.39 & 47.37 & 40.90 & 29.12 & 28.96 & 37.49 & 24.02 & 24.62 & 21.69 & 24.17 \\
\hline & \multicolumn{10}{|c|}{ Trace element (ppm) } \\
\hline $\mathrm{Li}(10)$ & 10.0 & b.d.l. & 10.0 & 17.9 & 16.7 & 19.8 & 16.9 & 16.1 & 17.5 & 11.4 \\
\hline Sc (1) & 42.0 & 37.0 & 36.0 & 26.2 & 26.9 & 26.2 & n.d. & 24.5 & 26.5 & n.d. \\
\hline V (5) & 323.0 & 326.0 & 361.0 & 207.0 & 212.0 & 213.0 & 68.0 & 62.0 & 63.0 & 75.0 \\
\hline $\mathrm{Cr}(10)$ & 120.0 & 140.0 & 30.0 & 4.0 & 5.0 & 2.0 & 8.0 & 3.0 & b.d.l. & 9.0 \\
\hline $\mathrm{Ni}(1)$ & 76.0 & 50.0 & 59.0 & 13.1 & 14.9 & 14.4 & 4.0 & 1.0 & 1.5 & 3.0 \\
\hline Zn (2) & 126.0 & 95.0 & 206.0 & 115.0 & 135.0 & 190.0 & 105.0 & 111.0 & 100.0 & 960.0 \\
\hline As $(0.1)$ & 1.0 & 0.2 & 0.2 & 0.6 & 0.3 & 0.4 & 2.7 & 1.5 & 1.9 & 1.0 \\
\hline $\operatorname{Se}(0.2)$ & 0.4 & 0.6 & 0.5 & 2.0 & 2.0 & 3.0 & 1.0 & 3.0 & 2.0 & 2.0 \\
\hline $\mathrm{Rb}(0.2)$ & 47.3 & 22.0 & 36.4 & 119.0 & 78.6 & 74.5 & 102.0 & 112.0 & 153.0 & 139.0 \\
\hline $\operatorname{Sr}(0.1)$ & 166.5 & 141.5 & 179.5 & 413.0 & 428.0 & 200.0 & 335.0 & 320.0 & 337.0 & 377.0 \\
\hline$Y(0.5)$ & 23.0 & 23.1 & 30.9 & 29.7 & 31.1 & 30.0 & 33.4 & 33.6 & 29.9 & 36.4 \\
\hline $\mathrm{Zr}(2)$ & 80.0 & 85.0 & 138.0 & 156.0 & 154.5 & 161.5 & 224.0 & 233.0 & 247.0 & 229.0 \\
\hline $\mathrm{Nb}(0.2)$ & 3.8 & 4.3 & 6.7 & 10.3 & 10.4 & 9.9 & 14.7 & 15.3 & 15.6 & 14.2 \\
\hline Mo (1) & b.d.1. & b.d.1. & b.d.1. & 4.0 & 1.5 & 12.6 & 1.6 & 1.8 & 1.8 & 2.0 \\
\hline $\mathrm{Cd}(0.5)$ & b.d.l. & b.d.l. & 0.5 & 0.1 & 0.1 & 0.2 & 0.1 & 0.1 & 0.1 & 1.3 \\
\hline Sn (1) & 1.0 & 1.0 & 1.0 & 1.4 & 1.4 & 1.4 & 1.8 & 1.7 & 2.6 & 2.0 \\
\hline $\mathrm{Sb}(0.05)$ & 0.3 & b.d.l. & 0.1 & 0.1 & 0.1 & 0.1 & 0.1 & 0.1 & 0.3 & 0.1 \\
\hline $\mathrm{Cs}(0.01)$ & 0.6 & 0.5 & 0.2 & 1.6 & 1.2 & 1.3 & 2.5 & 0.7 & 3.1 & 0.8 \\
\hline $\mathrm{Ba}(0.5)$ & 200.0 & 155.0 & 251.0 & 440.0 & 580.0 & 470.0 & 810.0 & 860.0 & 830.0 & 650.0 \\
\hline $\mathrm{La}(0.5)$ & 9.7 & 9.1 & 16.5 & 33.9 & 34.9 & 35.6 & 56.6 & 54.2 & 47.0 & 52.9 \\
\hline $\mathrm{Ce}(0.5)$ & 20.3 & 20.2 & 35.0 & 78.3 & 82.2 & 81.3 & 104.0 & 110.0 & 91.0 & 114.5 \\
\hline $\operatorname{Pr}(0.03)$ & 2.6 & 2.6 & 4.3 & 8.6 & 8.9 & 8.8 & 13.6 & 13.3 & 11.1 & 12.9 \\
\hline $\mathrm{Nd}(0.1)$ & 11.8 & 10.9 & 17.9 & 35.2 & 36.5 & 35.6 & 52.0 & 50.1 & 44.6 & 49.8 \\
\hline $\operatorname{Sm}(0.03)$ & 3.1 & 2.8 & 4.2 & 7.1 & 7.2 & 7.0 & 9.4 & 9.1 & 8.1 & 8.8 \\
\hline $\mathrm{Eu}(0.03)$ & 1.0 & 1.0 & 1.2 & 2.0 & 2.1 & 1.9 & 2.3 & 2.2 & 2.1 & 2.9 \\
\hline Gd (0.05) & 3.8 & 3.4 & 4.7 & 6.1 & 6.3 & 6.2 & 8.5 & 8.3 & 7.9 & 8.8 \\
\hline $\mathrm{Tb}(0.01)$ & 0.7 & 0.6 & 0.9 & 0.9 & 1.0 & 1.0 & 1.3 & 1.2 & 1.1 & 1.1 \\
\hline Dy $(0.05)$ & 4.2 & 3.9 & 5.5 & 5.0 & 5.1 & 5.0 & 6.0 & 6.2 & 5.7 & 6.2 \\
\hline Ho $(0.01)$ & 0.9 & 0.9 & 1.2 & 1.0 & 1.0 & 1.0 & 1.3 & 1.2 & 1.2 & 1.1 \\
\hline $\operatorname{Er}(0.03)$ & 2.6 & 2.6 & 3.2 & 2.6 & 2.6 & 2.6 & 3.5 & 3.5 & 3.3 & 3.4 \\
\hline $\operatorname{Tm}(0.01)$ & 0.4 & 0.4 & 0.5 & 0.4 & 0.3 & 0.4 & 0.5 & 0.5 & 0.5 & 0.5 \\
\hline $\mathrm{Yb}(0.03)$ & 2.7 & 2.5 & 3.4 & 2.2 & 2.2 & 2.2 & 3.2 & 3.2 & 3.1 & 2.9 \\
\hline $\mathrm{Lu}(0.01)$ & 0.4 & 0.4 & 0.5 & 0.3 & 0.3 & 0.3 & 0.5 & 0.5 & 0.5 & 0.4 \\
\hline $\mathrm{Ta}(0.1)$ & 0.3 & 0.3 & 0.5 & 0.6 & 0.6 & 0.6 & 0.9 & 0.9 & 1.0 & 1.0 \\
\hline $\mathrm{Pb}(2)$ & 9.0 & 2.0 & 11.0 & 11.5 & 12.3 & 18.7 & 36.8 & 9.1 & 13.3 & 7.0 \\
\hline $\mathrm{Bi}(0.01)$ & 0.0 & 0.0 & 0.0 & 0.1 & 0.1 & 0.1 & b.d.l. & b.d.l. & 0.1 & 0.1 \\
\hline $\operatorname{Th}(0.05)$ & 1.8 & 2.0 & 4.1 & 6.8 & 6.7 & 6.4 & 11.5 & 11.6 & 12.0 & 11.4 \\
\hline $\mathrm{U}(0.05)$ & 0.6 & 0.4 & 0.9 & 1.5 & 1.4 & 1.3 & 2.5 & 2.5 & 2.4 & 2.9 \\
\hline
\end{tabular}




\section{Figure Captions}

464 Figure 1. A simplified map of the Sudbury impact structure, showing the Whitewater Group, the 465 primary components of the Sudbury Igneous Complex, the Offset Dykes (named on map), and 466 the fractured footwall target rocks of the Southern Province and Superior Province. Modified 467 from OGS bedrock 1:250,000 (2003) and Wallbridge Mining Company Limited mapping.

468 Figure 2. Geologic map of the Pele Offset Dykes, their surrounding host rocks, and sample 469 locations.

470 Figure 3. Field photographs and photomicrographs from the Pele QD dykes. A. Coarse grained

471 QD from the Central dyke. B. Fine grained QD from the Eastern dyke with small granite clasts.

472 C. Photomicrograph from the Central Pele dyke with granophyric intergrowths of quartz and 473 feldspar. Plagioclase is overprinted by epidote and sericite alteration. D. Photomicrograph from 474 the Eastern Pele dyke with coarse grained euhedral amphiboles partially altered to chlorite. E. 475 Photomicrograph from the Central Pele dyke with a thin vein of fine grained carbonate and mica.

476 F. Photomicrograph from the Western Pele dyke showing chlorite and a small euhedral 477 amphibole set in a quartz-rich matrix.

478 Figure 4. QAP normative diagram showing the lithological compositions of the Pele Offset 479 Dykes and nearby Nipissing Diabase dykes (after Streckeisen, 1976).

480 Figure 5. Comparison of the geochemical variations between the Pele Offset Dykes, the Foy 481 Offset Dyke, and the Granophyre and Norite units of the SIC. The data from the Foy (Pilles et al. 482 2017) and the SIC (Therriault et al., 2002) are depicted as ellipses, which represents the $p=0.95$ 483 Mahalanobis Contour Ellipses (De Maesschalck et al. 2000). A. $\mathrm{SiO}_{2}$ vs MgO. B. MgO vs. $\mathrm{TiO}_{2}$. 
484 C. La/Nb vs Th/Zr. D. Sr/Y vs La/Sm. E. Dy/Yb vs Dy/Dy*. Dy/Dy* was calculated using

485 modified chondritic normalizing values of Nakamura (1974) as reported by Kelley et al. (2003).

486 Figure 6. Spider diagram of average incompatible elements from the Pele dykes normalized to

487 the average Foy Offset Dyke (Tuchscherer and Spray 2002). The data from the Granophyre and

488 Norite units of the SIC are from Therriault et al. (2002).

489 Figure 7. Spider diagrams of REE normalized to the average quartz diorite (QD) from the Foy 490 dyke (Tuchscherer and Spray 2002). A. Samples from the Eastern Pele dyke. B. Samples from 491 the Central Pele dyke. C. Samples from the Western Pele dyke.

492 Figure 8. Robust principal component robust (RPC) analysis using major element oxides (A, $49382.8 \%$ of the total variation) and immobile elements (B, 89.7\% of the total variation) as 494 variables. Comparison of the geochemical variations between the Pele dykes, the Foy Offset 495 Dyke, and the Granophyre and Norite units of the SIC. The data from the Foy (Pilles et al. 2017) 496 and the SIC (Therriault et al., 2002) are depicted as ellipses, which represents the $\mathrm{p}=0.95$ 497 Mahalanobis Contour Ellipses (De Maesschalck et al. 2000). 


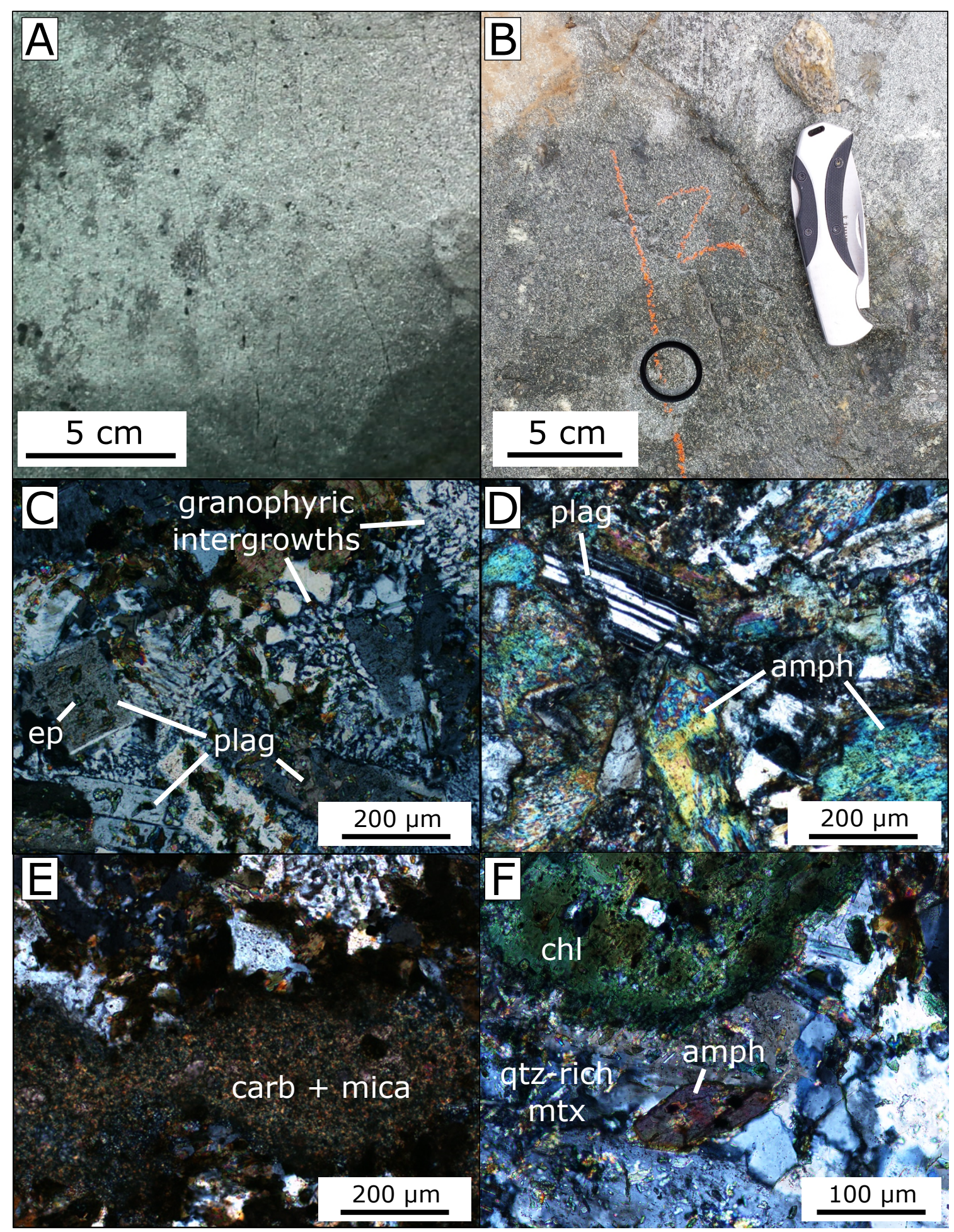




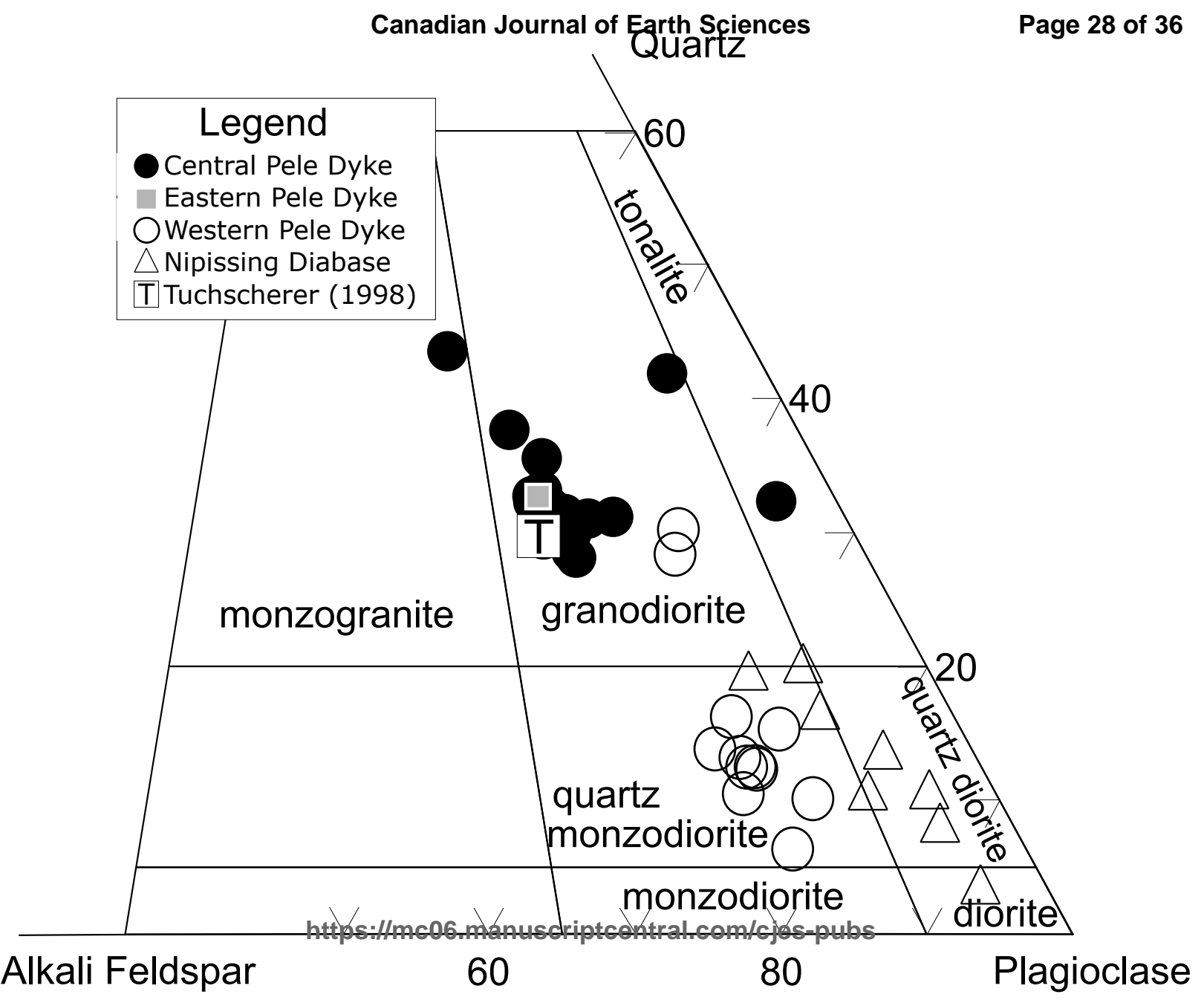




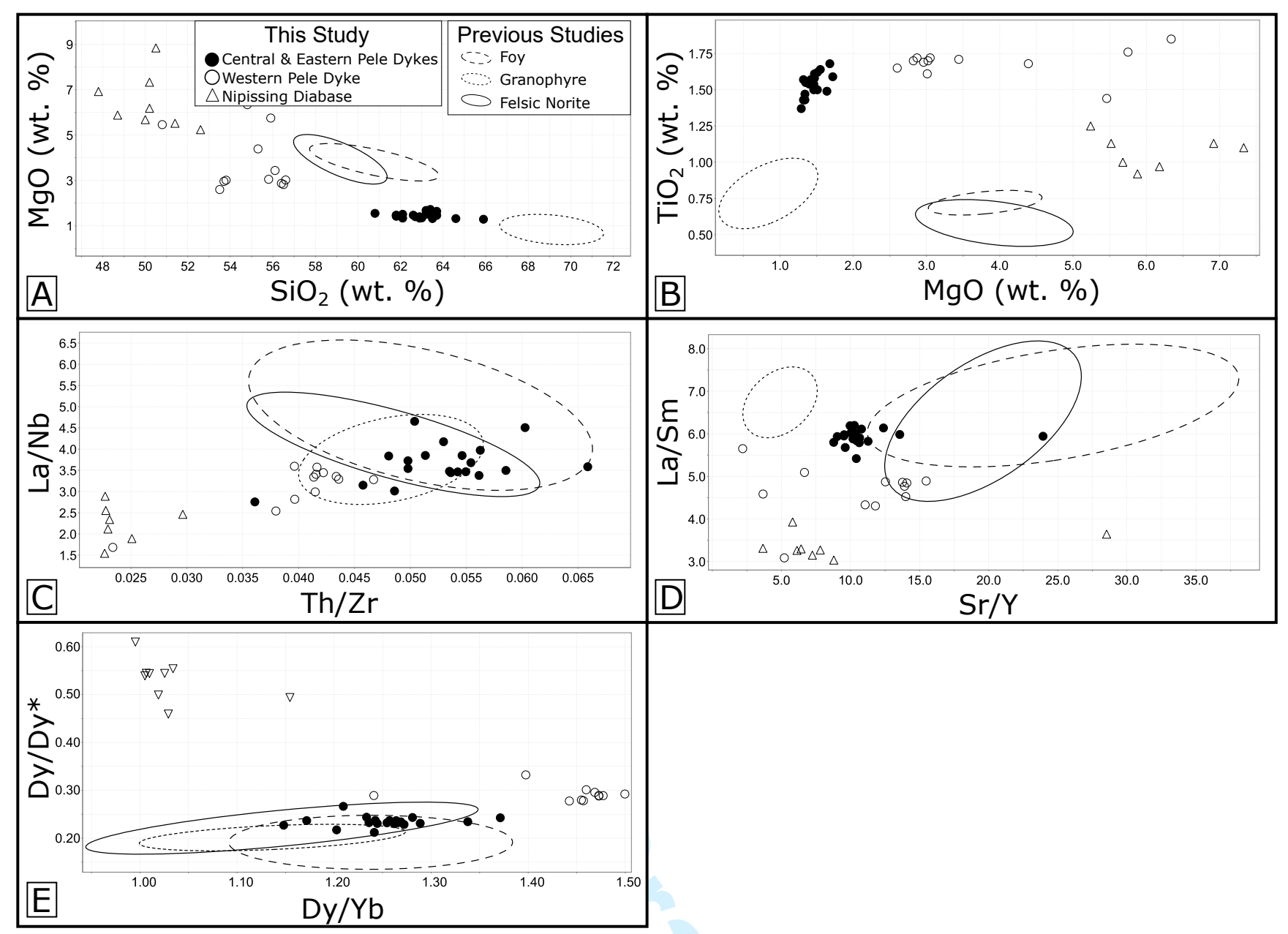




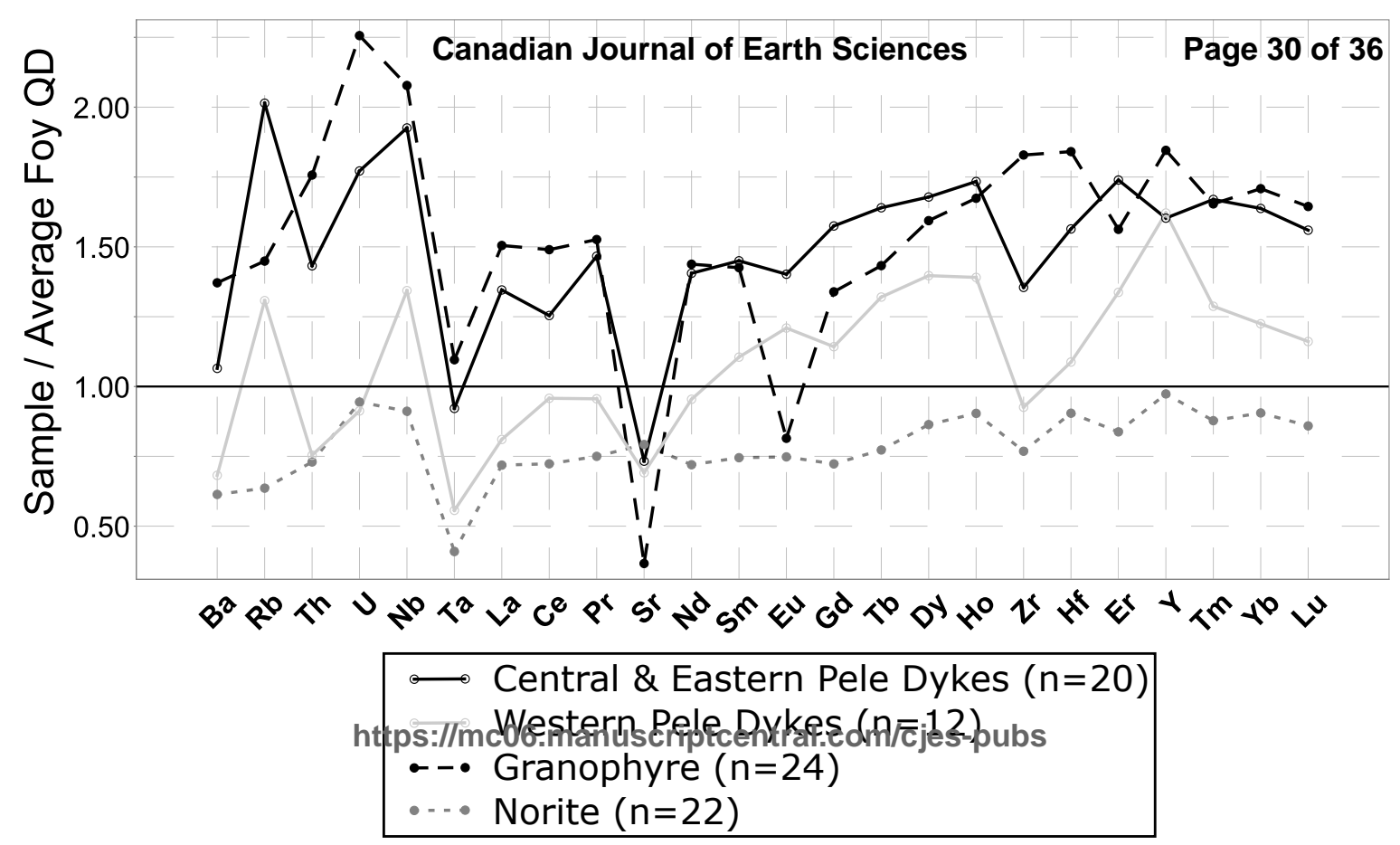




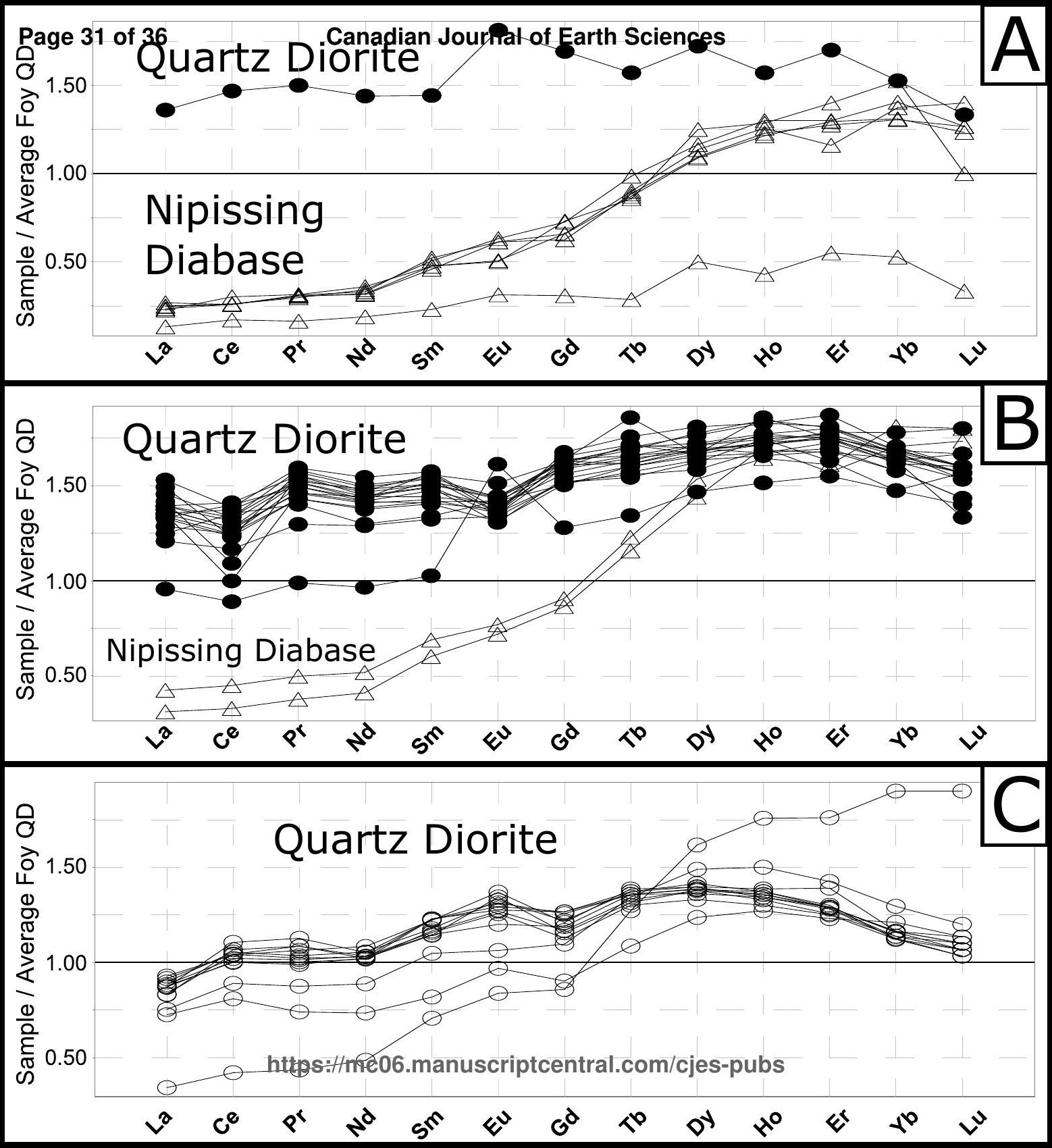




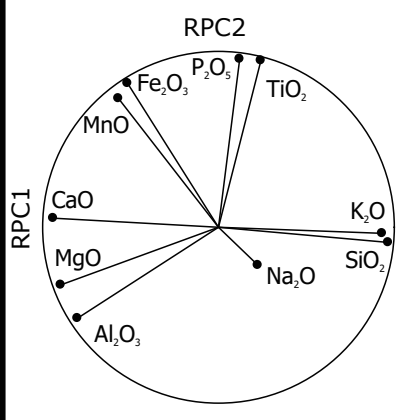

$\widehat{y} \stackrel{10}{ }$ Canadian Journal of Earth Sciences 8 ${ }^{8} \Delta$

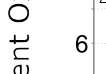

\section{O}

$6 \quad \Delta$

4. $\triangle \triangle$

$4 \triangle \triangle$

2 Previous Studies

0 … Foy

$\because . .$.$) Granophyre$

$-2 \bigcirc$ Felsic Norite

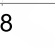

A

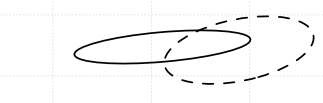

$\triangle$

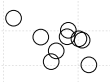

$\bigcirc$

○

This Stpdge 32 of 36

- Central \& Eastern Pele Dykes

Western Pele Dyke

$\triangle$ Nipissing Diabase
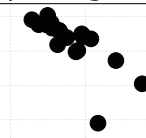

$\triangle$

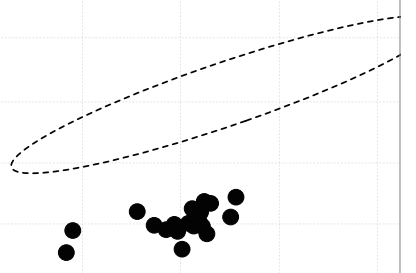

$-2$

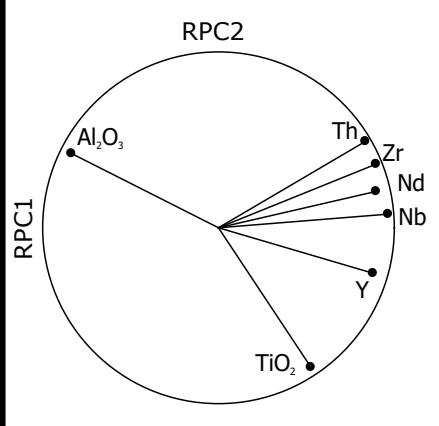

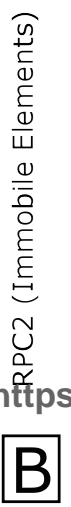

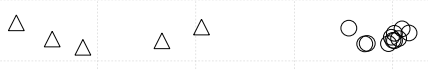

$-4 / /$ mc06.manuscriptcentral.com/cjes-pubs

$\begin{array}{lllllll}-5 & -4 & -3 & -2 & -1 & 0 & 1\end{array}$

RPC1 (Immobile Elements) 
Supplementary table: Geochemistry of the Pele Offset Dykes. Coordinates reported in NAD83. b.d.1. = below detection limit; n.d. = no data. Lower limits of detection are reported in parentheses.

\begin{tabular}{|c|c|c|c|c|c|c|c|c|c|c|}
\hline \multirow{4}{*}{$\begin{array}{r}\text { Sample ID } \\
\text { Easting } \\
\text { Northing }\end{array}$} & \multicolumn{10}{|c|}{ Central Pele Dyke } \\
\hline & SI-013 & 602863 & 604356 & 605021 & 703815 & 703827 & 703828 & 703829 & 703849 & 703835 \\
\hline & 476160 & 476157 & 476154 & 476151 & 476144 & 476011 & 476053 & 476022 & 475846 & 475916 \\
\hline & 5178115 & 5178118 & 5178071 & 5178093 & 5178725 & 5179513 & 5179287 & 5179497 & 5181313 & 5179858 \\
\hline & \multicolumn{10}{|c|}{ Major Oxide (weight \%) } \\
\hline $\mathrm{SiO}_{2}(0.01)$ & 61.80 & 63.50 & 62.10 & 60.80 & 63.70 & 61.80 & 63.20 & 62.60 & 62.90 & 61.80 \\
\hline $\mathrm{Al}_{2} \mathrm{O}_{3}(0.01)$ & 12.30 & 12.80 & 13.20 & 12.70 & 12.90 & 13.60 & 13.20 & 12.40 & 12.30 & 12.30 \\
\hline $\mathrm{Fe}_{2} \mathrm{O}_{3}(0.01)$ & 8.90 & 8.90 & 9.40 & 9.20 & 8.50 & 9.40 & 9.10 & 9.40 & 9.40 & 9.40 \\
\hline $\mathrm{CaO}(0.01)$ & 4.20 & 3.90 & 4.40 & 4.30 & 3.30 & 4.30 & 3.90 & 3.90 & 4.00 & 4.10 \\
\hline $\mathrm{MgO}(0.01)$ & 1.50 & 1.30 & 1.50 & 1.50 & 1.60 & 1.50 & 1.50 & 1.50 & 1.30 & 1.40 \\
\hline $\mathrm{Na}_{2} \mathrm{O}(0.01)$ & 3.40 & 3.30 & 3.40 & 3.20 & 3.40 & 3.30 & 3.20 & 3.20 & 3.10 & 3.20 \\
\hline $\mathrm{K}_{2} \mathrm{O}(0.01)$ & 2.50 & 2.70 & 2.70 & 2.50 & 2.80 & 2.70 & 2.70 & 2.60 & 2.80 & 2.50 \\
\hline $\mathrm{TiO}_{2}(0.01)$ & 1.50 & 1.40 & 1.60 & 1.60 & 1.50 & 1.60 & 1.50 & 1.60 & 1.50 & 1.60 \\
\hline $\mathrm{MnO}(0.01)$ & 0.10 & 0.20 & 0.20 & 0.10 & 0.10 & 0.10 & 0.20 & 0.20 & 0.10 & 0.10 \\
\hline $\mathrm{P}_{2} \mathrm{O}_{5}(0.01)$ & 0.50 & 0.50 & 0.50 & 0.50 & 0.50 & 0.60 & 0.50 & 0.50 & 0.50 & 0.50 \\
\hline $\mathrm{BaO}(0.01)$ & 0.10 & 0.10 & 0.10 & 0.10 & 0.10 & 0.10 & 0.10 & 0.10 & 0.10 & 0.10 \\
\hline $\mathrm{S}(0.01)$ & b.d.l. & 0.10 & 0.10 & 0.10 & b.d.l. & b.d.l. & 0.10 & b.d.1. & b.d.l. & b.d.l. \\
\hline Total & 97.60 & 98.60 & 99.20 & 96.80 & 98.40 & 99.00 & 99.30 & 98.10 & 98.10 & 97.10 \\
\hline \multirow[t]{2}{*}{ Mg number } & 25.03 & 22.44 & 24.02 & 24.41 & 27.16 & 24.02 & 24.62 & 24.02 & 21.51 & 22.78 \\
\hline & \multicolumn{10}{|c|}{ Trace Elements (ppm) } \\
\hline $\mathrm{Li}(10)$ & 10.0 & 12.6 & 16.9 & 23.1 & 12.1 & 20.4 & 16.1 & 23.3 & 27.7 & 17.1 \\
\hline $\operatorname{Sc}(1)$ & 23.0 & n.d. & n.d. & n.d. & 24.6 & 25.5 & 24.5 & 23.8 & 19.5 & 26.1 \\
\hline$V(5)$ & 86.0 & 49.0 & 68.0 & 82.0 & 66.0 & 79.0 & 62.0 & 71.0 & 57.0 & 70.0 \\
\hline $\mathrm{Cr}(10)$ & 10.0 & 1.0 & 8.0 & 3.0 & 2.0 & 7.0 & 3.0 & 3.0 & b.d.l. & 1.0 \\
\hline $\mathrm{Ni}(1)$ & b.d.l. & b.d.l. & 4.0 & 2.0 & 2.0 & 4.0 & 1.0 & 3.0 & 1.0 & 2.3 \\
\hline $\mathrm{Zn}(2)$ & 142.0 & 195.0 & 105.0 & 92.0 & 52.0 & 106.0 & 111.0 & 150.0 & 145.0 & 141.0 \\
\hline As $(0.1)$ & 2.1 & 1.9 & 2.7 & 2.1 & 0.7 & 1.8 & 1.5 & 1.4 & 1.0 & 1.4 \\
\hline $\operatorname{Se}(0.2)$ & 0.6 & 0.5 & 1.0 & 1.0 & 3.0 & 3.0 & 3.0 & 1.0 & 1.0 & 1.0 \\
\hline $\mathrm{Rb}(0.2)$ & 111.0 & 79.0 & 102.0 & 107.0 & 230.0 & 220.0 & 112.0 & 101.0 & 206.0 & 120.0 \\
\hline $\operatorname{Sr}(0.1)$ & 325.0 & 297.0 & 335.0 & 340.0 & 301.0 & 325.0 & 320.0 & 309.0 & 316.0 & 317.0 \\
\hline$Y(0.5)$ & 31.2 & 28.9 & 33.4 & 33.4 & 33.3 & 33.8 & 33.6 & 29.8 & 23.3 & 30.4 \\
\hline $\mathrm{Zr}(2)$ & 232.0 & 192.0 & 224.0 & 198.0 & 236.0 & 207.0 & 233.0 & 227.0 & 198.0 & 228.0 \\
\hline $\mathrm{Nb}(0.2)$ & 13.5 & 13.2 & 14.7 & 14.7 & 15.4 & 15.3 & 15.3 & 13.9 & 11.3 & 14.8 \\
\hline Mo (1) & b.d.l. & 1.7 & 1.6 & 1.5 & 1.3 & 1.6 & 1.8 & 1.6 & 1.3 & 1.7 \\
\hline $\mathrm{Cd}(0.5)$ & b.d.l. & 0.2 & 0.1 & 0.1 & 0.1 & b.d.l. & 0.1 & 0.1 & b.d.l. & 0.1 \\
\hline Sn (1) & 2.0 & 2.3 & 1.8 & 1.9 & 1.5 & 2.2 & 1.7 & 1.9 & 1.5 & 2.0 \\
\hline $\mathrm{Sb}(0.05)$ & 0.1 & 0.2 & 0.1 & 0.1 & 0.1 & 0.1 & 0.1 & 0.2 & 0.1 & 0.2 \\
\hline Cs $(0.01)$ & 2.0 & 0.7 & 2.5 & 2.4 & 1.5 & 2.8 & 0.7 & 1.2 & 2.3 & 2.2 \\
\hline $\mathrm{Ba}(0.5)$ & 935.0 & 870.0 & 810.0 & 820.0 & 600.0 & 720.0 & 860.0 & 870.0 & 820.0 & 840.0 \\
\hline $\mathrm{La}(0.5)$ & 51.8 & 59.5 & 56.6 & 54.1 & 48.5 & 52.7 & 54.2 & 53.5 & 52.6 & 50.0 \\
\hline $\mathrm{Ce}(0.5)$ & 109.0 & 108.0 & 104.0 & 102.5 & 105.5 & 107.0 & 110.0 & 99.7 & 77.9 & 97.4 \\
\hline $\operatorname{Pr}(0.03)$ & 12.8 & 13.7 & 13.6 & 13.1 & 12.0 & 13.0 & 13.3 & 13.0 & 12.5 & 12.3 \\
\hline $\mathrm{Nd}(0.1)$ & 49.5 & 53.4 & 52.0 & 51.2 & 44.9 & 49.4 & 50.1 & 49.9 & 49.9 & 47.6 \\
\hline $\operatorname{Sm}(0.03)$ & 9.6 & 9.6 & 9.4 & 9.2 & 8.2 & 9.3 & 9.1 & 9.1 & 8.8 & 8.5 \\
\hline $\mathrm{Eu}(0.03)$ & 2.2 & 2.2 & 2.3 & 2.3 & 2.3 & 2.3 & 2.2 & 2.1 & 2.2 & 2.1 \\
\hline Gd (0.05) & 7.9 & 8.6 & 8.5 & 8.3 & 7.8 & 8.4 & 8.3 & 8.0 & 8.5 & 7.8 \\
\hline $\mathrm{Tb}(0.01)$ & 1.1 & 1.2 & 1.3 & 1.2 & 1.1 & 1.2 & 1.2 & 1.1 & 1.2 & 1.1 \\
\hline Dy (0.05) & 5.8 & 6.0 & 6.0 & 6.1 & 6.0 & 6.4 & 6.2 & 5.9 & 6.1 & 5.9 \\
\hline Ho $(0.01)$ & 1.2 & 1.2 & 1.3 & 1.2 & 1.2 & 1.3 & 1.2 & 1.2 & 1.2 & 1.2 \\
\hline $\operatorname{Er}(0.03)$ & 3.3 & 3.5 & 3.5 & 3.5 & 3.5 & 3.6 & 3.5 & 3.4 & 3.5 & 3.4 \\
\hline $\operatorname{Tm}(0.01)$ & 0.5 & 0.4 & 0.5 & 0.5 & 0.5 & 0.5 & 0.5 & 0.5 & 0.5 & 0.5 \\
\hline $\mathrm{Yb}(0.03)$ & 2.8 & 3.1 & 3.2 & 3.1 & 3.1 & 3.2 & 3.2 & 3.0 & 3.1 & 3.0 \\
\hline $\mathrm{Lu}(0.01)$ & 0.5 & 0.4 & 0.5 & 0.5 & 0.5 & 0.5 & 0.5 & 0.4 & 0.5 & 0.4 \\
\hline $\mathrm{Ta}(0.1)$ & 0.8 & 1.0 & 0.9 & 0.9 & 0.9 & 0.9 & 0.9 & 0.9 & 0.7 & 0.9 \\
\hline $\mathrm{Pb}(2)$ & 24.0 & 26.6 & 36.8 & 18.0 & 41.1 & 12.2 & 9.1 & 12.3 & 8.6 & 12.4 \\
\hline $\mathrm{Bi}(0.01)$ & 0.1 & 0.1 & b.d.l. & b.d.l. & b.d.l. & 0.8 & b.d.l. & 0.1 & 0.1 & 0.1 \\
\hline $\operatorname{Th}(0.05)$ & 11.1 & 11.6 & 11.5 & 11.0 & 10.8 & 11.1 & 11.6 & 12.4 & 10.0 & 12.8 \\
\hline $\mathrm{U}(0.05)$ & 2.5 & 2.5 & 2.5 & 2.3 & 2.5 & 2.5 & 2.5 & 2.2 & 1.9 & 2.3 \\
\hline
\end{tabular}




\begin{tabular}{|c|c|c|c|c|c|c|c|c|c|c|}
\hline & \multicolumn{9}{|c|}{ Central Pele Dyke } & \multirow{2}{*}{$\begin{array}{c}\begin{array}{c}\text { Eastern } \\
\text { Pele Dyke }\end{array} \\
604275\end{array}$} \\
\hline & 703837 & 703838 & 703840 & 703841 & 703842 & 703843 & 703846 & 703847 & 703848 & \\
\hline & 475858 & 475866 & 476202 & 475844 & 475847 & 475846 & 475834 & 475825 & 475829 & 476489 \\
\hline & 5180477 & 5180593 & 5178221 & 5181276 & 5181230 & 5181235 & 5181407 & 5181144 & 5181034 & 5180762 \\
\hline & \multicolumn{10}{|c|}{ Major Oxide (weight \%) } \\
\hline $\mathrm{SiO}_{2}(0.01)$ & 63.00 & 63.40 & 63.20 & 62.10 & 65.90 & 62.70 & 63.50 & 64.60 & 63.70 & 62.90 \\
\hline $\mathrm{Al}_{2} \mathrm{O}_{3}(0.01)$ & 12.60 & 12.60 & 12.70 & 12.20 & 12.00 & 12.80 & 12.50 & 12.20 & 12.40 & 12.60 \\
\hline $\mathrm{Fe}_{2} \mathrm{O}_{3}(0.01)$ & 9.30 & 9.30 & 9.30 & 9.10 & 6.70 & 9.70 & 9.60 & 9.30 & 9.40 & 8.70 \\
\hline $\mathrm{CaO}(0.01)$ & 4.00 & 3.50 & 4.00 & 4.00 & 6.90 & 4.00 & 4.20 & 4.10 & 3.90 & 4.90 \\
\hline $\mathrm{MgO}(0.01)$ & 1.30 & 1.70 & 1.70 & 1.30 & 1.30 & 1.40 & 1.50 & 1.30 & 1.50 & 1.40 \\
\hline $\mathrm{Na}_{2} \mathrm{O}(0.01)$ & 3.40 & 3.60 & 3.60 & 3.00 & 1.10 & 3.20 & 2.20 & 3.00 & 3.10 & 3.20 \\
\hline $\mathrm{K}_{2} \mathrm{O}(0.01)$ & 2.90 & 2.40 & 2.10 & 2.70 & 2.80 & 2.70 & 2.70 & 2.50 & 2.70 & 2.70 \\
\hline $\mathrm{TiO}_{2}(0.01)$ & 1.50 & 1.60 & 1.70 & 1.40 & 1.40 & 1.50 & 1.50 & 1.60 & 1.50 & 1.50 \\
\hline $\mathrm{MnO}(0.01)$ & 0.10 & 0.10 & 0.10 & 0.10 & 0.10 & 0.10 & 0.10 & 0.10 & 0.10 & 0.10 \\
\hline $\mathrm{P}_{2} \mathrm{O}_{5}(0.01)$ & 0.50 & 0.50 & 0.50 & 0.50 & 0.30 & 0.50 & 0.50 & 0.40 & 0.50 & 0.50 \\
\hline $\mathrm{BaO}(0.01)$ & 0.10 & 0.10 & 0.10 & 0.10 & 0.10 & 0.10 & 0.10 & 0.10 & 0.10 & 0.10 \\
\hline $\mathrm{S}(0.01)$ & b.d.l. & b.d.l. & b.d.l. & 0.10 & b.d.1. & b.d.l. & b.d.l. & b.d.l. & b.d.1. & b.d.l. \\
\hline Total & 99.00 & 98.80 & 99.20 & 96.70 & 98.80 & 99.00 & 98.50 & 99.40 & 98.90 & 98.70 \\
\hline \multirow[t]{2}{*}{ Mg number } & 21.69 & 26.59 & 26.59 & 22.06 & 27.77 & 22.24 & 23.64 & 21.69 & 24.02 & 24.17 \\
\hline & \multicolumn{10}{|c|}{ Trace Elements (ppm) } \\
\hline $\operatorname{Li}(10)$ & 22.2 & 22.4 & 20.1 & 34.6 & 14.0 & 22.8 & 43.1 & 17.5 & 17.1 & 11.4 \\
\hline $\operatorname{Sc}(1)$ & 25.0 & 23.0 & 26.8 & 26.5 & 22.8 & 25.5 & 25.9 & 26.5 & 25.4 & n.d. \\
\hline $\mathrm{V}(5)$ & 59.0 & 62.0 & 87.0 & 60.0 & 88.0 & 61.0 & 61.0 & 63.0 & 63.0 & 75.0 \\
\hline $\operatorname{Cr}(10)$ & 1.0 & b.d.l. & b.d.l. & 2.0 & 1.0 & 1.0 & b.d.l. & b.d.l. & b.d.l. & 9.0 \\
\hline $\mathrm{Ni}(1)$ & 1.6 & 1.9 & 2.8 & 1.3 & 5.1 & 1.5 & 1.5 & 1.5 & 1.5 & 3.0 \\
\hline $\mathrm{Zn}(2)$ & 111.0 & 63.0 & 110.0 & 121.0 & 40.0 & 143.0 & 111.0 & 100.0 & 93.0 & 960.0 \\
\hline As $(0.1)$ & 1.8 & 1.0 & 0.8 & 1.1 & 1.5 & 1.6 & 0.9 & 1.9 & 1.5 & 1.0 \\
\hline $\operatorname{Se}(0.2)$ & 1.0 & 1.0 & 2.0 & 2.0 & 1.0 & 2.0 & 1.0 & 2.0 & 1.0 & 2.0 \\
\hline $\mathrm{Rb}(0.2)$ & 101.0 & 108.0 & 144.0 & 109.0 & 117.0 & 125.0 & 365.0 & 153.0 & 120.0 & 139.0 \\
\hline $\operatorname{Sr}(0.1)$ & 319.0 & 245.0 & 316.0 & 339.0 & 682.0 & 327.0 & 374.0 & 337.0 & 288.0 & 377.0 \\
\hline $\mathrm{Y}(0.5)$ & 30.0 & 27.9 & 31.7 & 31.8 & 28.5 & 30.3 & 30.2 & 29.9 & 30.2 & 36.4 \\
\hline $\mathrm{Zr}(2)$ & 242.0 & 219.0 & 240.0 & 234.0 & 230.0 & 243.0 & 208.0 & 247.0 & 236.0 & 229.0 \\
\hline $\mathrm{Nb}(0.2)$ & 15.0 & 13.2 & 14.6 & 15.5 & 13.5 & 15.1 & 14.9 & 15.6 & 14.9 & 14.2 \\
\hline Mo (1) & 1.7 & 1.5 & 1.0 & 1.9 & 1.5 & 1.9 & 1.1 & 1.8 & 1.7 & 2.0 \\
\hline $\mathrm{Cd}(0.5)$ & 0.1 & b.d.l. & b.d.l. & b.d.l. & 0.1 & 0.1 & b.d.l. & 0.1 & b.d.l. & 1.3 \\
\hline $\mathrm{Sn}(1)$ & 2.6 & 2.4 & 1.0 & 1.9 & 2.3 & 1.9 & 2.1 & 2.6 & 2.4 & 2.0 \\
\hline $\mathrm{Sb}(0.05)$ & 0.2 & 0.1 & 0.1 & 0.2 & 0.4 & 0.2 & 0.1 & 0.3 & 0.2 & 0.1 \\
\hline Cs $(0.01)$ & 2.6 & 0.9 & 3.6 & 2.8 & 1.8 & 2.6 & 3.4 & 3.1 & 2.4 & 0.8 \\
\hline $\mathrm{Ba}(0.5)$ & 930.0 & 610.0 & 510.0 & 940.0 & 670.0 & 850.0 & 810.0 & 830.0 & 860.0 & 650.0 \\
\hline $\mathrm{La}(0.5)$ & 52.0 & 55.1 & 58.0 & 54.2 & 37.2 & 52.5 & 53.4 & 47.0 & 51.6 & 52.9 \\
\hline $\mathrm{Ce}(0.5)$ & 97.1 & 85.1 & 95.9 & 104.0 & 69.4 & 99.0 & 99.8 & 91.0 & 96.2 & 114.5 \\
\hline $\operatorname{Pr}(0.03)$ & 12.8 & 13.4 & 13.5 & 13.2 & 8.5 & 12.6 & 12.6 & 11.1 & 12.3 & 12.9 \\
\hline $\mathrm{Nd}(0.1)$ & 49.1 & 51.0 & 51.6 & 50.7 & 33.4 & 49.0 & 48.7 & 44.6 & 47.9 & 49.8 \\
\hline $\operatorname{Sm}(0.03)$ & 9.0 & 9.5 & 9.4 & 9.2 & 6.3 & 8.6 & 8.7 & 8.1 & 8.6 & 8.8 \\
\hline $\mathrm{Eu}(0.03)$ & 2.2 & 2.4 & 2.2 & 2.3 & 2.6 & 2.2 & 2.2 & 2.1 & 2.3 & 2.9 \\
\hline $\mathrm{Gd}(0.05)$ & 8.1 & 8.5 & 8.7 & 8.4 & 6.6 & 8.4 & 8.5 & 7.9 & 8.3 & 8.8 \\
\hline $\mathrm{Tb}(0.01)$ & 1.1 & 1.2 & 1.2 & 1.2 & 0.9 & 1.1 & 1.1 & 1.1 & 1.1 & 1.1 \\
\hline Dy $(0.05)$ & 6.2 & 6.3 & 6.5 & 6.2 & 5.3 & 6.0 & 6.1 & 5.7 & 6.0 & 6.2 \\
\hline Но $(0.01)$ & 1.2 & 1.3 & 1.9 & 1.2 & 1.1 & 1.2 & 1.2 & 1.2 & 1.2 & 1.1 \\
\hline $\operatorname{Er}(0.03)$ & 3.5 & 3.6 & 3.7 & 3.6 & 3.1 & 3.6 & 3.4 & 3.3 & 3.5 & 3.4 \\
\hline $\operatorname{Tm}(0.01)$ & 0.5 & 0.5 & 0.5 & 0.5 & 0.4 & 0.5 & 0.5 & 0.5 & 0.5 & 0.5 \\
\hline $\mathrm{Yb}(0.03)$ & 3.2 & 3.2 & 3.2 & 3.2 & 2.8 & 3.4 & 3.1 & 3.1 & 3.1 & 2.9 \\
\hline $\mathrm{Lu}(0.01)$ & 0.5 & 0.5 & 0.5 & 0.5 & 0.4 & 0.5 & 0.5 & 0.5 & 0.5 & 0.4 \\
\hline $\mathrm{Ta}(0.1)$ & 1.0 & 0.9 & 1.0 & 1.0 & 0.9 & 1.0 & 1.0 & 1.0 & 1.0 & 1.0 \\
\hline $\mathrm{Pb}(2)$ & 10.3 & 6.1 & 8.1 & 12.4 & 15.0 & 12.1 & 11.1 & 13.3 & 10.0 & 7.0 \\
\hline $\mathrm{Bi}(0.01)$ & 0.1 & 0.1 & b.d.l. & 0.1 & 0.1 & 0.1 & 0.1 & 0.1 & 0.1 & 0.1 \\
\hline Th $(0.05)$ & 13.3 & 11.6 & 13.5 & 13.7 & 8.3 & 13.0 & 13.7 & 12.0 & 12.8 & 11.4 \\
\hline $\mathrm{U}(0.05)$ & 3.0 & 2.3 & 2.8 & 2.5 & 3.8 & 2.4 & 4.2 & 2.4 & 2.4 & 2.9 \\
\hline
\end{tabular}




\begin{tabular}{|c|c|c|c|c|c|c|c|c|c|c|}
\hline & \multicolumn{10}{|c|}{ Western Pele Dyke } \\
\hline & 809926 & 809928 & 809929 & 809930 & 809954 & 809955 & 809956 & 809957 & 809958 & 809959 \\
\hline & 474894 & 475228 & 475150 & 475300 & 474590 & 474650 & 474563 & 474497 & 474506 & 474492 \\
\hline & 5180877 & 5180466 & 5180499 & 5180424 & 5181408 & 5181260 & 5181515 & 5181745 & 5181834 & 5181574 \\
\hline & \multicolumn{10}{|c|}{ Major Oxide (weight \%) } \\
\hline $\mathrm{SiO}_{2}(0.01)$ & 56.50 & 55.90 & 54.80 & 55.80 & 56.40 & 56.60 & 56.10 & 55.30 & 50.80 & 53.80 \\
\hline $\mathrm{Al}_{2} \mathrm{O}_{3}(0.01)$ & 12.60 & 13.00 & 13.60 & 12.90 & 12.80 & 12.80 & 12.50 & 12.40 & 12.35 & 12.50 \\
\hline $\mathrm{Fe}_{2} \mathrm{O}_{3}(0.01)$ & 13.60 & 13.55 & 11.75 & 13.90 & 13.95 & 13.55 & 14.25 & 14.50 & 17.15 & 13.55 \\
\hline $\mathrm{CaO}(0.01)$ & 6.19 & 2.07 & 1.86 & 5.86 & 5.74 & 5.52 & 5.11 & 4.59 & 7.86 & 6.03 \\
\hline $\mathrm{MgO}(0.01)$ & 2.82 & 5.75 & 6.34 & 3.05 & 2.87 & 3.02 & 3.44 & 4.39 & 5.46 & 3.01 \\
\hline $\mathrm{Na}_{2} \mathrm{O}(0.01)$ & 3.32 & 2.79 & 2.90 & 3.43 & 3.78 & 3.71 & 3.69 & 3.95 & 2.04 & 3.04 \\
\hline $\mathrm{K}_{2} \mathrm{O}(0.01)$ & 1.61 & 1.10 & 1.18 & 1.30 & 1.63 & 1.71 & 1.65 & 1.27 & 1.32 & 1.76 \\
\hline $\mathrm{TiO}_{2}(0.01)$ & 1.70 & 1.76 & 1.85 & 1.72 & 1.72 & 1.70 & 1.71 & 1.68 & 1.44 & 1.61 \\
\hline $\mathrm{MnO}(0.01)$ & 0.19 & 0.09 & 0.09 & 0.19 & 0.19 & 0.20 & 0.20 & 0.23 & 0.27 & 0.17 \\
\hline $\mathrm{P}_{2} \mathrm{O}_{5}(0.01)$ & 0.40 & 0.41 & 0.42 & 0.39 & 0.40 & 0.40 & 0.39 & 0.39 & 0.15 & 0.39 \\
\hline $\mathrm{BaO}(0.01)$ & 0.05 & 0.02 & 0.03 & 0.06 & 0.07 & 0.08 & 0.08 & 0.06 & 0.04 & 0.07 \\
\hline $\mathrm{S}(0.01)$ & 0.09 & 0.10 & 0.06 & 0.09 & 0.10 & 0.09 & 0.10 & 0.25 & 0.05 & 0.15 \\
\hline Total & 99.13 & 96.56 & 94.89 & 98.74 & 99.70 & 99.43 & 99.26 & 99.03 & 99.00 & 96.13 \\
\hline \multirow[t]{2}{*}{ Mg number } & 29.12 & 45.67 & 51.67 & 30.30 & 28.96 & 30.63 & 32.35 & 37.49 & 38.68 & 30.56 \\
\hline & \multicolumn{10}{|c|}{ Trace element $(\mathrm{ppm})$} \\
\hline$\overline{\mathrm{Li}(10)}$ & 17.9 & 29.4 & 40.5 & 20.1 & 16.7 & 21.1 & 25.9 & 19.8 & 17.8 & 25.0 \\
\hline $\operatorname{Sc}(1)$ & 26.2 & 27.4 & 28.3 & 27.9 & 26.9 & 26.6 & 27.0 & 26.2 & 53.4 & 26.9 \\
\hline $\mathrm{V}(5)$ & 207.0 & 212.0 & 235.0 & 232.0 & 212.0 & 216.0 & 226.0 & 213.0 & 359.0 & 214.0 \\
\hline $\mathrm{Cr}(10)$ & 4.0 & 4.0 & 2.0 & 4.0 & 5.0 & 3.0 & 4.0 & 2.0 & 49.0 & 2.0 \\
\hline $\mathrm{Ni}(1)$ & 13.1 & 17.1 & 17.2 & 15.2 & 14.9 & 15.3 & 14.7 & 14.4 & 62.0 & 14.4 \\
\hline $\mathrm{Zn}(2)$ & 115.0 & 107.0 & 102.0 & 187.0 & 135.0 & 175.0 & 174.0 & 190.0 & 165.0 & 112.0 \\
\hline As $(0.1)$ & 0.6 & 1.1 & 0.3 & 3.0 & 0.3 & 1.3 & 3.0 & 0.4 & 0.3 & 0.5 \\
\hline $\operatorname{Se}(0.2)$ & 2.0 & 2.0 & 2.0 & 3.0 & 2.0 & 2.0 & 2.0 & 3.0 & 2.0 & 2.0 \\
\hline $\mathrm{Rb}(0.2)$ & 119.0 & 106.5 & 96.9 & 66.1 & 78.6 & 79.9 & 75.9 & 74.5 & 113.5 & 131.5 \\
\hline $\operatorname{Sr}(0.1)$ & 413.0 & 118.5 & 56.6 & 458.0 & 428.0 & 425.0 & 372.0 & 200.0 & 213.0 & 438.0 \\
\hline$Y(0.5)$ & 29.7 & 32.3 & 25.8 & 29.6 & 31.1 & 30.2 & 29.7 & 30.0 & 40.9 & 31.3 \\
\hline $\operatorname{Zr}(2)$ & 156.0 & 174.0 & 187.0 & 144.5 & 154.5 & 158.5 & 154.0 & 161.5 & 94.1 & 152.0 \\
\hline $\mathrm{Nb}(0.2)$ & 10.3 & 10.4 & 11.1 & 9.9 & 10.4 & 10.1 & 10.1 & 9.9 & 7.9 & 10.3 \\
\hline Mo (1) & 4.0 & 1.4 & 1.6 & 1.6 & 1.5 & 1.2 & 1.5 & 12.6 & 0.8 & 1.3 \\
\hline $\mathrm{Cd}(0.5)$ & 0.1 & 0.0 & 0.0 & 0.4 & 0.1 & 0.3 & 0.3 & 0.2 & 0.2 & 0.1 \\
\hline Sn (1) & 1.4 & 1.5 & 1.6 & 1.5 & 1.4 & 1.4 & 1.4 & 1.4 & 1.2 & 1.5 \\
\hline $\mathrm{Sb}(0.05)$ & 0.1 & 0.1 & 0.1 & 0.1 & 0.1 & 0.1 & 0.1 & 0.1 & 0.1 & 0.1 \\
\hline Cs $(0.01)$ & 1.6 & 1.4 & 1.1 & 1.5 & 1.2 & 1.6 & 1.7 & 1.3 & 1.4 & 1.8 \\
\hline $\mathrm{Ba}(0.5)$ & 440.0 & 180.0 & 230.0 & 530.0 & 580.0 & 680.0 & 700.0 & 470.0 & 330.0 & 630.0 \\
\hline $\mathrm{La}(0.5)$ & 33.9 & 29.3 & 28.2 & 34.1 & 34.9 & 36.1 & 34.4 & 35.6 & 13.3 & 33.8 \\
\hline $\mathrm{Ce}(0.5)$ & 78.3 & 69.4 & 63.1 & 78.0 & 82.2 & 81.1 & 79.6 & 81.3 & 32.8 & 86.2 \\
\hline $\operatorname{Pr}(0.03)$ & 8.6 & 7.5 & 6.4 & 8.5 & 8.9 & 9.1 & 8.7 & 8.8 & 3.7 & 9.7 \\
\hline $\mathrm{Nd}(0.1)$ & 35.2 & 30.7 & 25.4 & 35.4 & 36.5 & 37.5 & 35.7 & 35.6 & 16.8 & 36.4 \\
\hline $\operatorname{Sm}(0.03)$ & 7.1 & 6.4 & 5.0 & 7.0 & 7.2 & 7.5 & 7.1 & 7.0 & 4.3 & 7.5 \\
\hline $\mathrm{Eu}(0.03)$ & 2.0 & 1.7 & 1.6 & 2.2 & 2.1 & 2.2 & 2.0 & 1.9 & 1.3 & 2.1 \\
\hline Gd (0.05) & 6.1 & 5.7 & 4.7 & 6.0 & 6.3 & 6.3 & 5.9 & 6.2 & 4.5 & 6.6 \\
\hline $\mathrm{Tb}(0.01)$ & 0.9 & 0.9 & 0.8 & 0.9 & 1.0 & 1.0 & 0.9 & 1.0 & 0.9 & 1.0 \\
\hline Dy $(0.05)$ & 5.0 & 5.4 & 4.5 & 5.0 & 5.1 & 5.0 & 4.8 & 5.0 & 5.8 & 5.0 \\
\hline Нo $(0.01)$ & 1.0 & 1.1 & 0.9 & 0.9 & 1.0 & 0.9 & 0.9 & 1.0 & 1.2 & 1.0 \\
\hline $\operatorname{Er}(0.03)$ & 2.6 & 2.9 & 2.5 & 2.5 & 2.6 & 2.6 & 2.5 & 2.6 & 3.5 & 2.6 \\
\hline $\operatorname{Tm}(0.01)$ & 0.4 & 0.4 & 0.4 & 0.3 & 0.3 & 0.4 & 0.4 & 0.4 & 0.6 & 0.4 \\
\hline $\mathrm{Yb}(0.03)$ & 2.2 & 2.5 & 2.3 & 2.2 & 2.2 & 2.2 & 2.1 & 2.2 & 3.6 & 2.1 \\
\hline $\mathrm{Lu}(0.01)$ & 0.3 & 0.4 & 0.3 & 0.3 & 0.3 & 0.3 & 0.3 & 0.3 & 0.6 & 0.3 \\
\hline $\mathrm{Ta}(0.1)$ & 0.6 & 0.6 & 0.6 & 0.5 & 0.6 & 0.6 & 0.6 & 0.6 & 0.4 & 0.6 \\
\hline $\mathrm{Pb}(2)$ & 11.5 & 4.3 & 2.5 & 45.6 & 12.3 & 36.5 & 18.9 & 18.7 & 23.8 & 11.3 \\
\hline $\mathrm{Bi}(0.01)$ & 0.1 & 0.1 & 0.1 & 0.1 & 0.1 & 0.1 & 0.1 & 0.1 & 0.0 & 0.1 \\
\hline $\operatorname{Th}(0.05)$ & 6.8 & 6.9 & 7.1 & 6.1 & 6.7 & 6.6 & 6.4 & 6.4 & 2.2 & 7.1 \\
\hline $\mathrm{U}(0.05)$ & 1.5 & 1.6 & 1.6 & 1.3 & 1.4 & 1.3 & 1.3 & 1.3 & 0.6 & 1.5 \\
\hline
\end{tabular}




\begin{tabular}{|c|c|c|c|c|c|c|c|c|c|c|}
\hline & \multicolumn{5}{|c|}{ Western Pele Dyke } & \multicolumn{5}{|c|}{ Nipissing Diabase } \\
\hline & 809960 & 809963 & 120202 & 120501 & SI-004 & SI-005 & 603522 & 604270 & SI-010 & SI-011 \\
\hline & 475433 & 475580 & 476752 & 476752 & 476738 & 476734 & 476167 & 476499 & 476157 & 476162 \\
\hline & 5180271 & 5180050 & 5179554 & 5179554 & 5179600 & 5179594 & 5178860 & 5180865 & 5178242 & 5178231 \\
\hline & \multicolumn{10}{|c|}{ Major Oxide (weight \%) } \\
\hline $\mathrm{SiO}_{2}(0.01)$ & 53.50 & 53.70 & 48.70 & 50.20 & 50.20 & 50.00 & 50.50 & 47.80 & 51.40 & 52.60 \\
\hline $\mathrm{Al}_{2} \mathrm{O}_{3}(0.01)$ & 12.60 & 12.65 & 14.25 & 13.40 & 13.05 & 15.50 & 15.65 & 13.35 & 12.65 & 13.20 \\
\hline $\mathrm{Fe}_{2} \mathrm{O}_{3}(0.01)$ & 13.40 & 13.40 & 13.35 & 14.15 & 13.70 & 12.50 & 8.32 & 15.05 & 14.45 & 15.00 \\
\hline $\mathrm{CaO}(0.01)$ & 5.51 & 6.17 & 9.68 & 9.83 & 7.49 & 10.80 & 10.70 & 6.38 & 8.66 & 8.73 \\
\hline $\operatorname{MgO}(0.01)$ & 2.60 & 2.96 & 5.88 & 6.18 & 7.33 & 5.68 & 8.84 & 6.92 & 5.52 & 5.24 \\
\hline $\mathrm{Na}_{2} \mathrm{O}(0.01)$ & 3.61 & 3.33 & 2.55 & 2.13 & 3.35 & 2.16 & 2.72 & 3.46 & 2.15 & 2.54 \\
\hline $\mathrm{K}_{2} \mathrm{O}(0.01)$ & 1.74 & 1.55 & 0.83 & 0.85 & 0.41 & 0.62 & 0.42 & 0.46 & 1.27 & 0.86 \\
\hline $\mathrm{TiO}_{2}(0.01)$ & 1.65 & 1.69 & 0.92 & 0.97 & 1.10 & 1.00 & 0.50 & 1.13 & 1.13 & 1.25 \\
\hline $\mathrm{MnO}(0.01)$ & 0.17 & 0.17 & 0.21 & 0.21 & 0.25 & 0.20 & 0.13 & 0.35 & 0.24 & 0.26 \\
\hline $\mathrm{P}_{2} \mathrm{O}_{5}(0.01)$ & 0.34 & 0.33 & 0.08 & 0.09 & 0.09 & 0.08 & 0.04 & 0.14 & 0.11 & 0.15 \\
\hline $\mathrm{BaO}(0.01)$ & 0.08 & 0.07 & 0.02 & 0.02 & 0.01 & 0.02 & 0.01 & 0.01 & 0.04 & 0.03 \\
\hline $\mathrm{S}(0.01)$ & 0.06 & 0.16 & 0.05 & 0.04 & 0.02 & 0.06 & 0.04 & 0.05 & 0.04 & 0.05 \\
\hline Total & 95.30 & 96.21 & 96.55 & 98.11 & 97.02 & 98.66 & 97.95 & 95.15 & 97.70 & 99.93 \\
\hline \multirow[t]{2}{*}{ Mg number } & 27.77 & 30.44 & 46.60 & 46.39 & 51.46 & 47.37 & 67.79 & 47.67 & 43.08 & 40.90 \\
\hline & \multicolumn{10}{|c|}{ Trace element (ppm) } \\
\hline Li (10) & 14.8 & 9.4 & 20.0 & 10.0 & 10.0 & b.d.l. & 10.1 & 11.4 & 10.0 & 10.0 \\
\hline $\mathrm{Sc}(1)$ & 28.4 & 27.3 & 38.0 & 42.0 & 43.0 & 37.0 & n.d. & n.d. & 40.0 & 36.0 \\
\hline V (5) & 225.0 & 234.0 & 296.0 & 323.0 & 330.0 & 326.0 & 177.0 & 292.0 & 364.0 & 361.0 \\
\hline $\operatorname{Cr}(10)$ & 2.0 & 5.0 & 100.0 & 120.0 & 80.0 & 140.0 & 227.0 & 173.0 & 50.0 & 30.0 \\
\hline $\mathrm{Ni}(1)$ & 13.8 & 15.2 & 62.0 & 76.0 & 63.0 & 50.0 & 145.0 & 69.7 & 68.0 & 59.0 \\
\hline $\mathrm{Zn}(2)$ & 134.0 & 124.0 & 113.0 & 126.0 & 147.0 & 95.0 & 84.0 & 208.0 & 149.0 & 206.0 \\
\hline As $(0.1)$ & 0.2 & 0.2 & 0.7 & 1.0 & 0.6 & 0.2 & 0.4 & 1.2 & 1.1 & 0.2 \\
\hline $\operatorname{Se}(0.2)$ & 2.0 & 2.0 & 0.4 & 0.4 & 0.4 & 0.6 & 1.0 & 2.0 & 0.6 & 0.5 \\
\hline $\mathrm{Rb}(0.2)$ & 80.3 & 97.5 & 50.5 & 47.3 & 19.9 & 22.0 & 17.0 & 23.0 & 77.4 & 36.4 \\
\hline $\operatorname{Sr}(0.1)$ & 374.0 & 324.0 & 169.5 & 166.5 & 87.5 & 141.5 & 311.0 & 247.0 & 194.0 & 179.5 \\
\hline $\mathrm{Y}(0.5)$ & 31.7 & 29.3 & 21.7 & 23.0 & 23.9 & 23.1 & 10.9 & 28.1 & 30.2 & 30.9 \\
\hline $\mathrm{Zr}(2)$ & 161.5 & 147.5 & 78.0 & 80.0 & 94.0 & 85.0 & 27.4 & 83.9 & 118.0 & 138.0 \\
\hline $\mathrm{Nb}(0.2)$ & 10.8 & 9.7 & 3.6 & 3.8 & 4.1 & 4.3 & 1.7 & 5.7 & 6.4 & 6.7 \\
\hline Mo (1) & 1.2 & 1.3 & b.d.l. & b.d.l. & b.d.l. & b.d.l. & 0.2 & 0.4 & b.d.l. & b.d.l. \\
\hline $\mathrm{Cd}(0.5)$ & 0.1 & 0.1 & b.d.l. & b.d.l. & 0.5 & b.d.l. & 0.2 & 0.0 & 0.5 & 0.5 \\
\hline $\operatorname{Sn}(1)$ & 1.5 & 1.4 & 1.0 & 1.0 & 1.0 & 1.0 & 0.5 & 1.0 & 1.0 & 1.0 \\
\hline $\mathrm{Sb}(0.05)$ & 0.1 & 0.1 & 0.2 & 0.3 & b.d.l. & b.d.l. & 0.1 & 0.1 & 0.1 & 0.1 \\
\hline Cs $(0.01)$ & 1.4 & 1.2 & 0.5 & 0.6 & 0.2 & 0.5 & 0.4 & 0.5 & 0.5 & 0.2 \\
\hline $\mathrm{Ba}(0.5)$ & 770.0 & 590.0 & 213.0 & 200.0 & 126.5 & 155.0 & 110.0 & 100.0 & 352.0 & 251.0 \\
\hline $\mathrm{La}(0.5)$ & 32.3 & 32.4 & 10.4 & 9.7 & 9.6 & 9.1 & 5.1 & 8.8 & 12.1 & 16.5 \\
\hline $\mathrm{Ce}(0.5)$ & 83.2 & 81.4 & 20.1 & 20.3 & 20.1 & 20.2 & 13.3 & 23.5 & 25.6 & 35.0 \\
\hline $\operatorname{Pr}(0.03)$ & 9.3 & 9.3 & 2.7 & 2.6 & 2.6 & 2.6 & 1.4 & 2.7 & 3.2 & 4.3 \\
\hline $\mathrm{Nd}(0.1)$ & 35.7 & 35.3 & 11.4 & 11.8 & 11.0 & 10.9 & 6.5 & 12.4 & 14.2 & 17.9 \\
\hline $\mathrm{Sm}(0.03)$ & 7.5 & 7.5 & 3.2 & 3.1 & 2.9 & 2.8 & 1.4 & 2.9 & 3.7 & 4.2 \\
\hline $\mathrm{Eu}(0.03)$ & 2.0 & 2.1 & 1.0 & 1.0 & 0.8 & 1.0 & 0.5 & 0.8 & 1.2 & 1.2 \\
\hline Gd (0.05) & 6.6 & 6.5 & 3.3 & 3.8 & 3.4 & 3.4 & 1.6 & 3.8 & 4.5 & 4.7 \\
\hline $\mathrm{Tb}(0.01)$ & 1.0 & 1.0 & 0.6 & 0.7 & 0.6 & 0.6 & 0.2 & 0.6 & 0.8 & 0.9 \\
\hline Dy $(0.05)$ & 5.0 & 4.9 & 3.9 & 4.2 & 4.1 & 3.9 & 1.8 & 4.5 & 5.2 & 5.5 \\
\hline Ho (0.01) & 1.0 & 0.9 & 0.9 & 0.9 & 0.9 & 0.9 & 0.3 & 0.9 & 1.2 & 1.2 \\
\hline $\operatorname{Er}(0.03)$ & 2.8 & 2.6 & 2.6 & 2.6 & 2.3 & 2.6 & 1.1 & 2.8 & 3.1 & 3.2 \\
\hline $\operatorname{Tm}(0.01)$ & 0.4 & 0.4 & 0.4 & 0.4 & 0.4 & 0.4 & 0.2 & 0.4 & 0.5 & 0.5 \\
\hline $\mathrm{Yb}(0.03)$ & 2.2 & 2.1 & 2.5 & 2.7 & 2.6 & 2.5 & 1.0 & 2.9 & 3.2 & 3.4 \\
\hline $\mathrm{Lu}(0.01)$ & 0.3 & 0.3 & 0.4 & 0.4 & 0.4 & 0.4 & 0.1 & 0.3 & 0.5 & 0.5 \\
\hline $\mathrm{Ta}(0.1)$ & 0.6 & 0.6 & 0.3 & 0.3 & 0.3 & 0.3 & 0.1 & 0.4 & 0.5 & 0.5 \\
\hline $\mathrm{Pb}(2)$ & 18.6 & 11.6 & 14.0 & 9.0 & 7.0 & 2.0 & 20.2 & 3.6 & 15.0 & 11.0 \\
\hline $\mathrm{Bi}(0.01)$ & 0.1 & 0.0 & 0.0 & 0.0 & 0.0 & 0.0 & 0.1 & 0.0 & 0.0 & 0.0 \\
\hline $\mathrm{Th}(0.05)$ & 6.7 & 6.1 & 1.8 & 1.8 & 2.2 & 2.0 & 2.6 & 1.9 & 3.0 & 4.1 \\
\hline $\mathrm{U}(0.05)$ & 1.4 & 1.3 & 0.5 & 0.6 & 0.5 & 0.4 & 0.3 & 0.5 & 0.8 & 0.9 \\
\hline
\end{tabular}

